\title{
Genome Size Study in the Valerianaceae: First Results and New Hypotheses
}

\author{
Oriane Hidalgo, ${ }^{1}$ Joël Mathez, ${ }^{2}$ Sònia Garcia, ${ }^{3}$ Teresa Garnatje, ${ }^{3}$ Jaume Pellicer, ${ }^{4}$ \\ and Joan Vallès 5 \\ ${ }^{1}$ Department of Environmental and Plant Biology, Ohio University, Porter Hall 500, Athens, OH 45701, USA \\ ${ }^{2}$ Institut Botanique, Université Montpellier II, UMR 5120 Botanique et Bioinformatique de l'Architecture des Plantes, \\ 163 rue Auguste Broussonnet, 34090 Montpellier, France \\ ${ }^{3}$ Institut Botànic de Barcelona (CSIC-ICUB), Passeig del Migdia s.n., 08038 Barcelona, Catalonia, Spain \\ ${ }^{4}$ Jodrell Laboratory, Royal Botanic Gardens, Kew, Richmond, Surrey TW9 3AB, UK \\ ${ }^{5}$ Laboratori de Botànica, Facultat de Farmàcia, Universitat de Barcelona, Av. Joan XXIII s.n., 08028 Barcelona, Catalonia, Spain
}

Correspondence should be addressed to Joan Vallès, joanvalles@ub.edu

Received 28 January 2010; Accepted 10 May 2010

Academic Editor: Jan Suda

Copyright (C) 2010 Oriane Hidalgo et al. This is an open access article distributed under the Creative Commons Attribution License, which permits unrestricted use, distribution, and reproduction in any medium, provided the original work is properly cited.

\begin{abstract}
The purpose of this study is to provide a new focus to contribute, from the perspective of genomic evolution, towards a better understanding of the Valerianaceae evolutionary history. Chromosome numbers were determined by Feulgen staining in 24 populations of 18 species (first count for Valerianella multidentata, $2 n=2 x=14-16$ ), and DNA contents were assessed by flow cytometry in 74 populations of 35 species (first assessments in all taxa but Centranthus ruber). A molecular phylogeny based on the $\operatorname{trn} \mathrm{L}-\operatorname{trn} \mathrm{F}$ and including 41 new sequences was established, with the first DNA sequence for Centranthus nevadensis, Valeriana rotundifolia, $V$. saxatilis, Valerianella multidentata, and $V$. turgida. This work is the first large genome size study devoted to the Valerianaceae, showing a range of DNA amounts from $2 \mathrm{C}=0.39 \mathrm{pg}$ (Valerianella turgida) to $2 \mathrm{C}=8.32 \mathrm{pg}$ (Valeriana officinalis). At the family level, changes in basic chromosome number and genome size coincide with or precede major shifts in the evolutionary history of the group, such as those concerning stamen number and floral symmetry.
\end{abstract}

\section{Introduction}

The family Valerianaceae (currently considered within the Caprifoliaceae s.l.; [1]) comprises ca. 400 species of which approximately 200 are included in Valeriana L., the biggest genus of the order Dipsacales. The Valerianaceae are cosmopolitan in their natural distribution, with the exceptions of Australia and the Pacific islands, where they were introduced, and can be nowadays considered as naturalized. Several of their representatives have economic interest as medicinal (e.g., V. officinalis L.), edible (e.g., Valerianella Mill., corn salad or lamb's lettuce), or ornamental plants (e.g., Centranthus DC.). The family always roused important scientific interest, and its study has broadly benefited from the new molecular techniques, especially the phylogenetic reconstructions. Recent phylogenies based on DNA sequencing [2-7] have considerably modified the traditional classification of the family [8-12]. Molecular results recognize only six genera: Centranthus, Fedia Gaertn., Nardostachys DC., Patrinia Juss., Valeriana (including Aretiastrum DC., Astrephia Dufr., Belonanthus Graebn., Phyllactis Pers., Porteria Hook., and Stangea Graebn.), and Valerianella. Plectritis (Lindl.) DC. is nested amongst South American Valeriana [5, 6]. Moreover, Bell [7] suggested a possible further taxonomic treatment of the family considering Fedia as a synonym of Valerianella. New genera may also be described for some of the Valeriana species that do not group with their congenerics in the phylogenetic reconstructions and make the genus Valeriana paraphyletic in its current circumscription. These are Valeriana longiflora Willk., which appears closely related 
to the genus Centranthus, and also Valeriana celtica L. and V. hardwickii Wall., branched somewhere between Nardostachys and Valerianella plus Fedia clades [4, 5].

Morphology in Valerianaceae is of great interest for its impressive diversity of forms, mainly resulting in adaptations to a wide range of ecological conditions (from the sea board to Andean páramos at $4000 \mathrm{~m}$ ), and concerning both vegetative and reproductive parts. This diversity has been especially well studied from the inflorescential structure perspective, with a common basic type, the thyrse, and very different forms and levels of complexity [13, 14]. Family Valerianaceae stands out in Dipsacales by presenting four different stamen numbers in a series (mainly four stamens in Patrinia and Nardostachys, three in Plectritis, Valerianella and Valeriana, two in Fedia, and one in Centranthus), while the other families show one or two distinct stamen numbers $[15,16]$. These features, along with some cases of strong corolla zygomorphy (in Centranthus, with 4:1 petals orientation; in Fedia, with 2:3 petals orientation) make the family very attractive for studying the genetic base of floral characters, which has been initiated through an evolutionary-developmental approach by [16, 17]. Evodevo studies highlight the crucial importance of duplication events in the evolution of genes involved in developmental processes (e.g., $[18,19])$. These events often correspond to whole duplication genome ([20], and references therein), making the karyological and cytogenetic data essential for understanding many evolutionary processes, as, for example, the floral morphological changes.

Nevertheless, karyological and cytogenetic data in Valerianaceae are basically limited to chromosome counts. The Valerianaceae exhibit a dysploid series of five basic chromosome numbers [21]: $x=15$ in American Valerianella, $x=$ 13 in Nardostachys, $x=11$ in Patrinia and Valeriana celtica, $x=8$ in Centranthus, Fedia, Valeriana and Valerianella, and $x=7$ in Valeriana and Valerianella. Polyploidization events are common, some genera being exclusively polyploid, such as Centranthus (tetraploid) or Fedia (tetraploid and hexaploid), while species of Patrinia and Valeriana can exhibit various ploidy levels, from diploid to octoploid. Hence, both polyploidy and dysploidy seem to have played a significant role in the differentiation and evolution of these plants. Cytogenetic data (such as banding, fluorescent in situ hybridization and genome size assessment) would certainly be of a great interest for understanding the evolution of the family. Nuclear DNA amount assessments constitute a fundamental complement to chromosome counts and, in addition, a powerful tool in order to establish the relationships between closely related taxonomical groups (e.g., in Echinops L.; [22], Orobanche L.; [23]), as well as to understand the evolution within related genera from a broader point of view (e.g., Liliaceae; [24], Orchidaceae; [25]). Furthermore, genome size is a useful tool to detect possible hybrid and polyploid origins of taxa (e.g., in Carthamus L.; [26], Nicotiana L.; [27], Artemisia L.; [28]), and intraspecific variation can reveal incipient speciation [29].

The aims of the present work are to: (a) enlarge the knowledge concerning nuclear DNA amounts in the Valerianaceae, to date limited to only one report ("Kentranthus ruber Druce" $1 \mathrm{C}=0.42 \mathrm{pg} ;$ [30]), (b) integrate these results with those of chromosome number and molecular phylogeny, and (c) provide a new focus that could contribute, from the perspective of genome evolution, to verify the hypotheses of previous works on the relationships among the above-mentioned genera.

\section{Material and Methods}

2.1. Plant Material. Table 1 shows the provenance of the species investigated. The sampling includes representatives of all the six genera considered in the family in regard to the results of molecular phylogenies [4-6]. Studied plants come from germinated cypselas, collected in the field or obtained from Botanic Gardens. Due to difficulties in germinating seeds of Valeriana representatives, whole individuals were collected in the field and cultivated in the Institut Botànic de Barcelona.

\subsection{Karyological and Cytogenetic Analyses}

2.2.1. Chromosome Counts and/or Determination of the Ploidy Level. Root tip meristems were obtained either by germinating seeds on wet filter paper in Petri dishes at room temperature, or from plants cultivated in pots in the greenhouse. They were pretreated with $0.002 \mathrm{M} \mathrm{8-}$ hydroxyquinoline for $3 \mathrm{~h}$ at $16^{\circ} \mathrm{C}$. Material was fixed in absolute ethanol, trichloromethane, and glacial acetic acid $(6: 3: 1)$ and stored in the fixative at $4^{\circ} \mathrm{C}$ during at least two days before processing. Samples were hydrolysed in $1 \mathrm{~N}$ $\mathrm{HCl}$ for $5 \mathrm{~min}$ at $60^{\circ} \mathrm{C}$, stained with $1 \%$ aqueous acetoorcein for $1 \mathrm{~h}$ minimum, and squashed on slides into a drop of $45 \%$ acetic acid-glycerol (9:1). Metaphase plates were photographed with a digital camera (Zeiss AxioCam HRm) mounted on a Zeiss Axioplan microscope, and images were analysed with Axio Vision Ac version 4.2.

2.2.2. Nuclear DNA Assessments. Leaf tissue of five individuals for each studied population was chopped in $600 \mu \mathrm{l}$ of LB01 isolation buffer [33] with a razor blade, together with the chosen internal standard. The species Petunia hybrida Vilm. 'PxPc6' $(2 \mathrm{C}=2.85 \mathrm{pg})$ and Pisum sativum L. 'Express long' $(2 \mathrm{C}=8.37 \mathrm{pg})$ were used as internal standards [34] to cover the range of $2 \mathrm{C}$-values found. Seeds of the standards were provided by the Institut des Sciences du Végétal (CNRS), Gif-sur-Yvette (France). For each individual, two independent samples were extracted and measured the same day. Samples were supplemented with $100 \mu \mathrm{g} / \mathrm{ml}$ of ribonuclease A (RNase A, Boehringer) and subsequently stained with $36 \mu \mathrm{l}$ of propidium iodide $(1 \mathrm{mg} / \mathrm{ml})$ to a final concentration of $60 \mu \mathrm{g} / \mathrm{ml}$ (Sigma-Aldrich Química), kept on ice for $20 \mathrm{~min}$ and measured in an Epics XL flow cytometer (Coulter Corporation). The instrument was set up with the standard configuration. Excitation of the sample was performed using a standard 488-nm air-cooled argon-ion laser at $15 \mathrm{~mW}$ power. Forward scatter (FSC), side scatter (SSC), and red $(620 \mathrm{~nm})$ fluorescence for propidium iodide were acquired. Optical alignment was based on optimized 


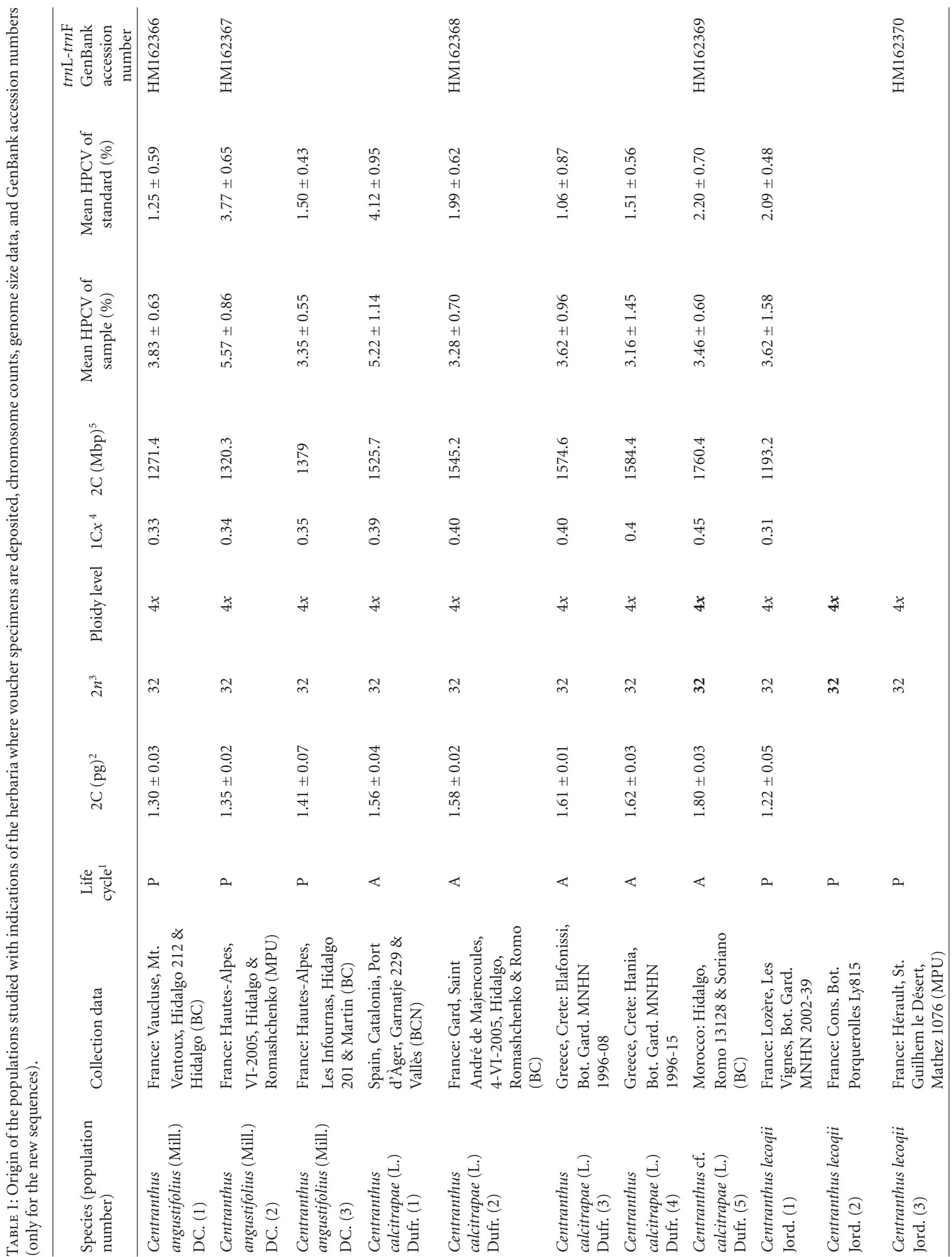




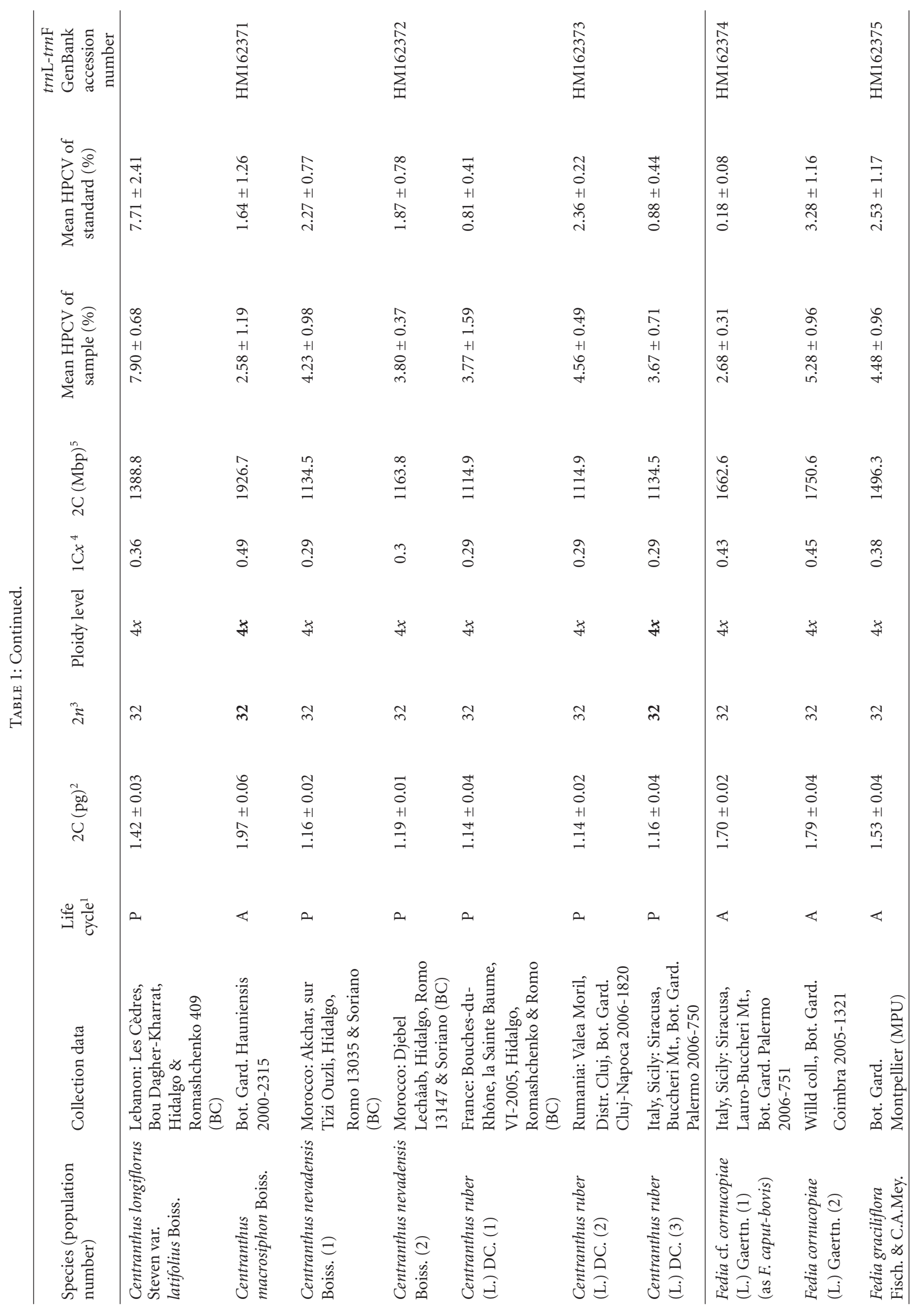




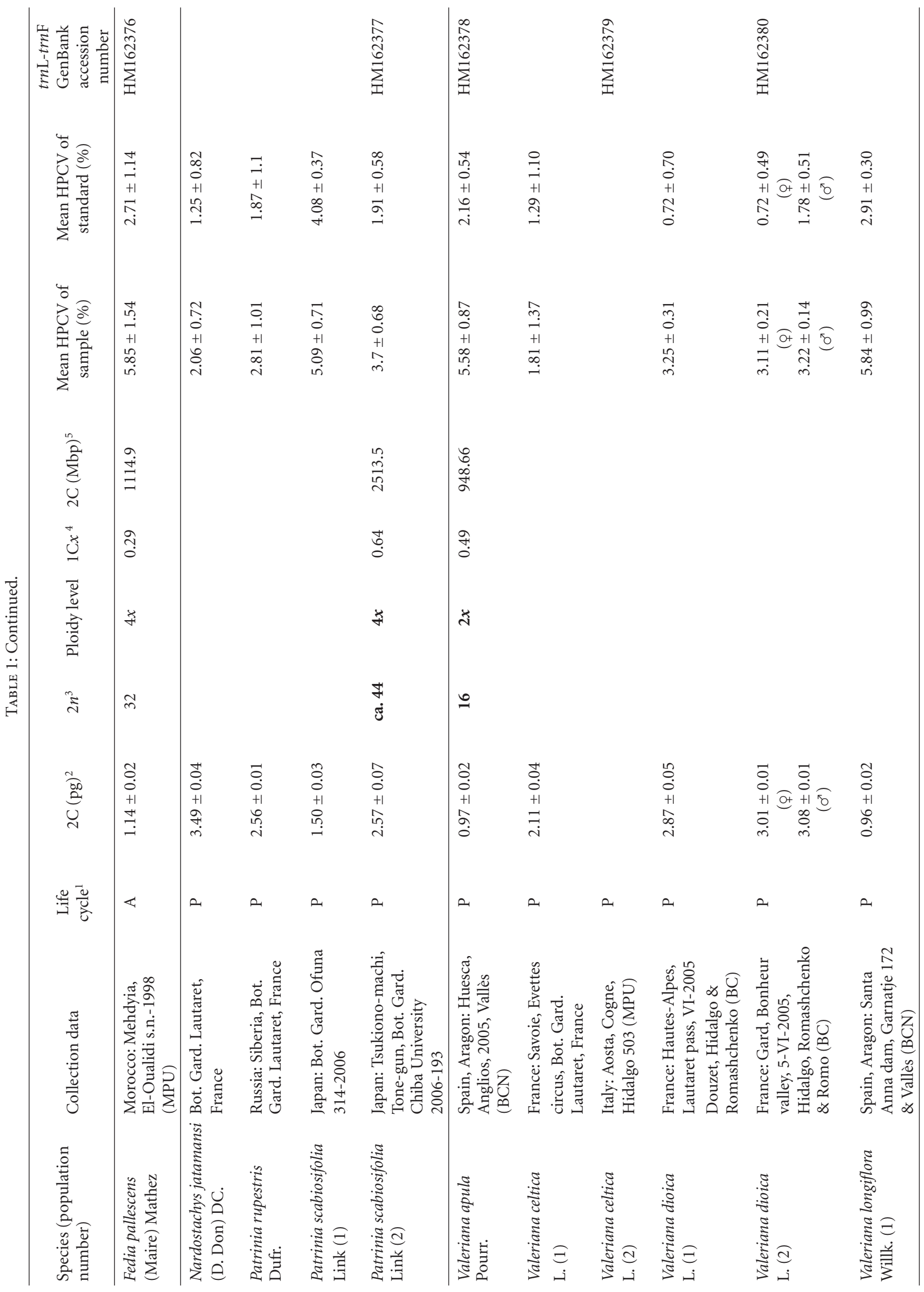




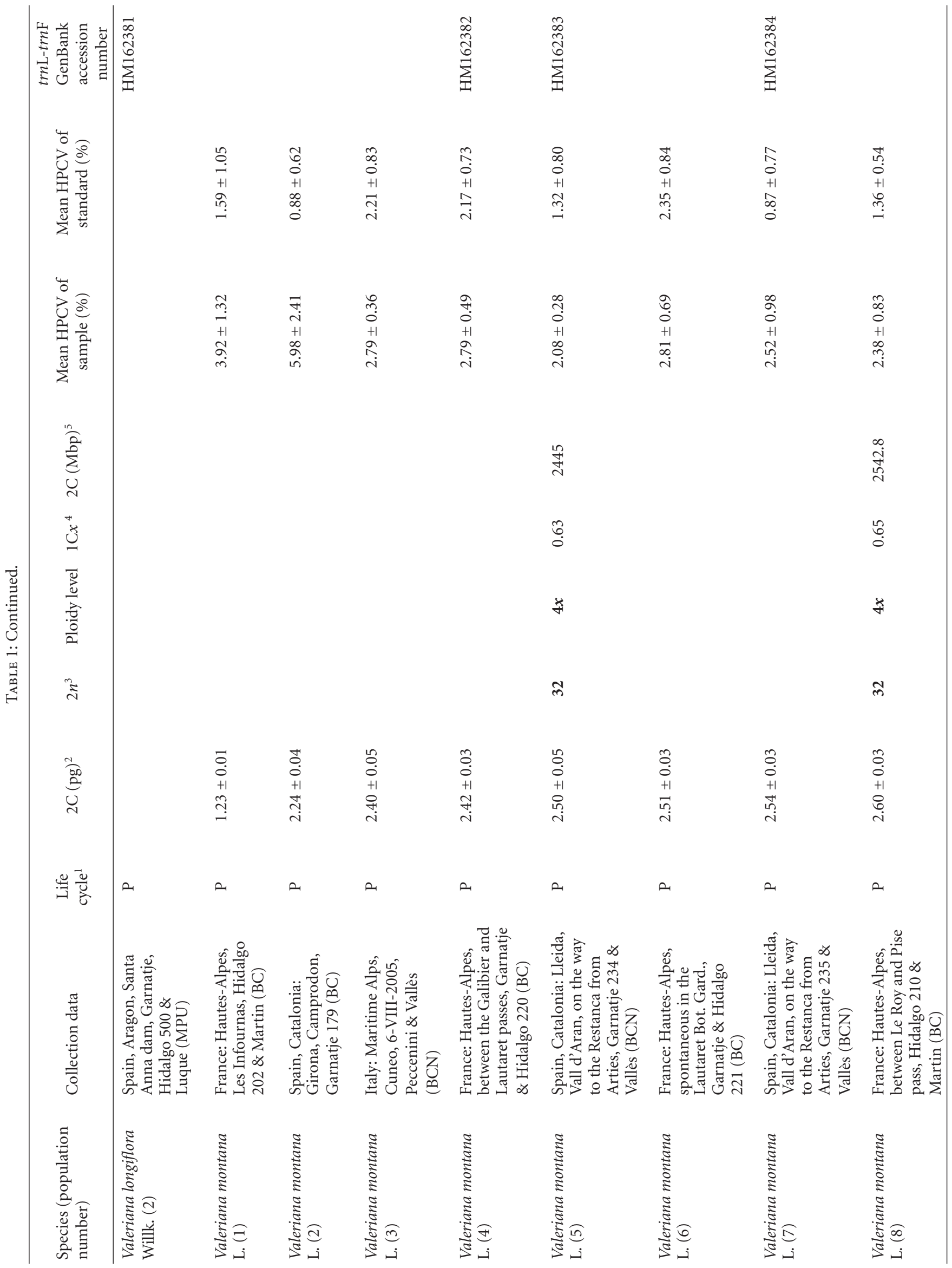




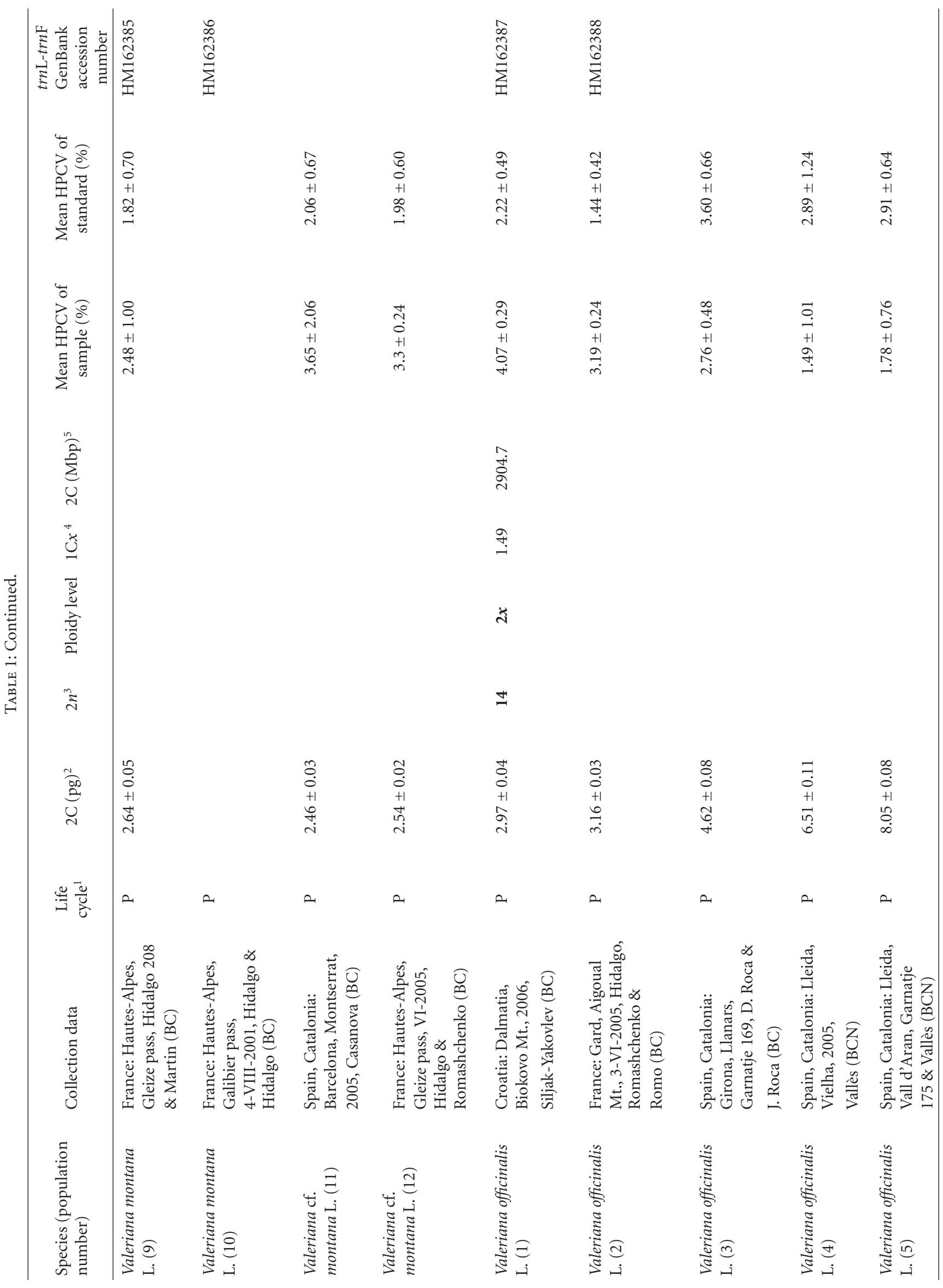




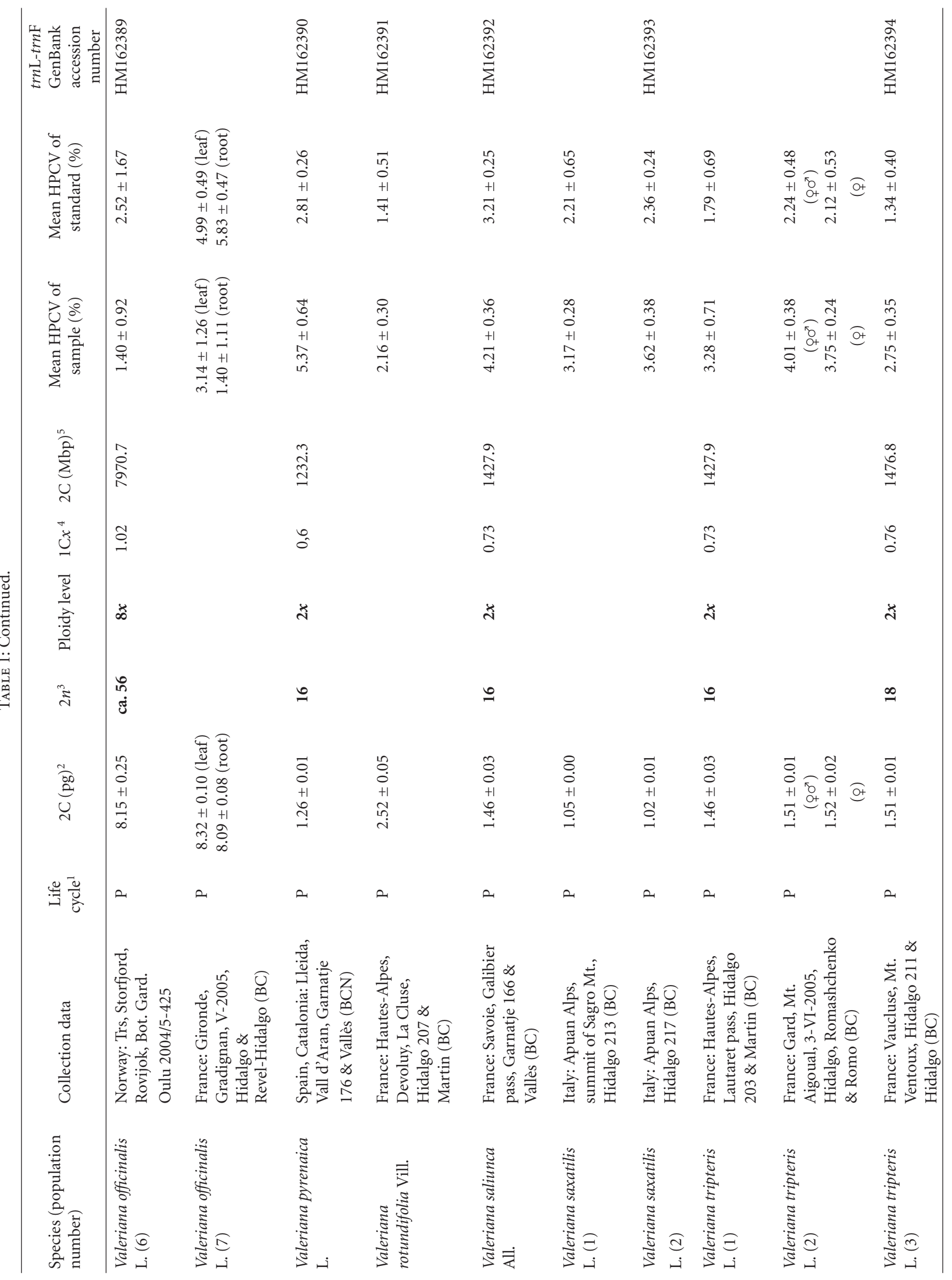




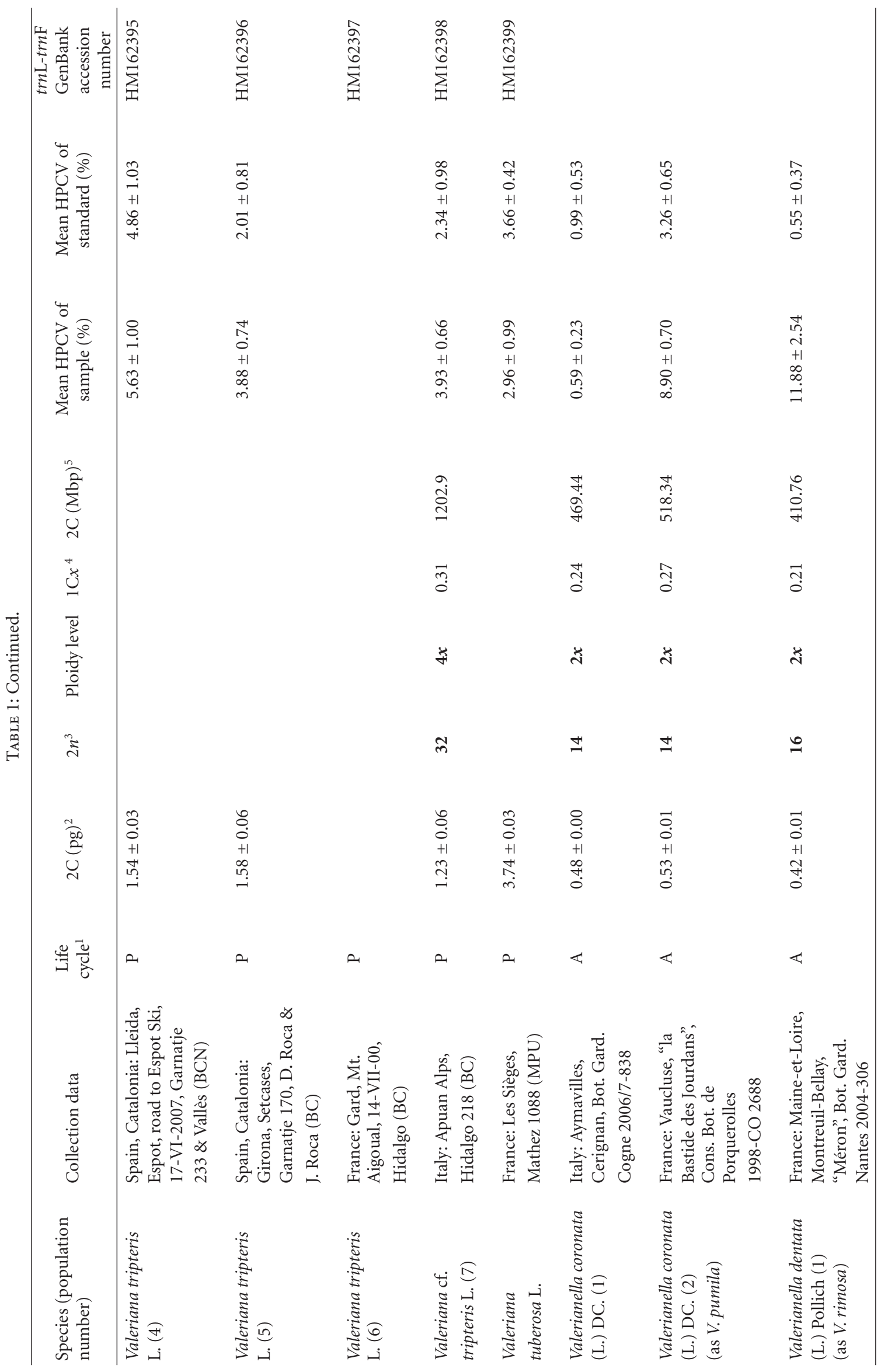




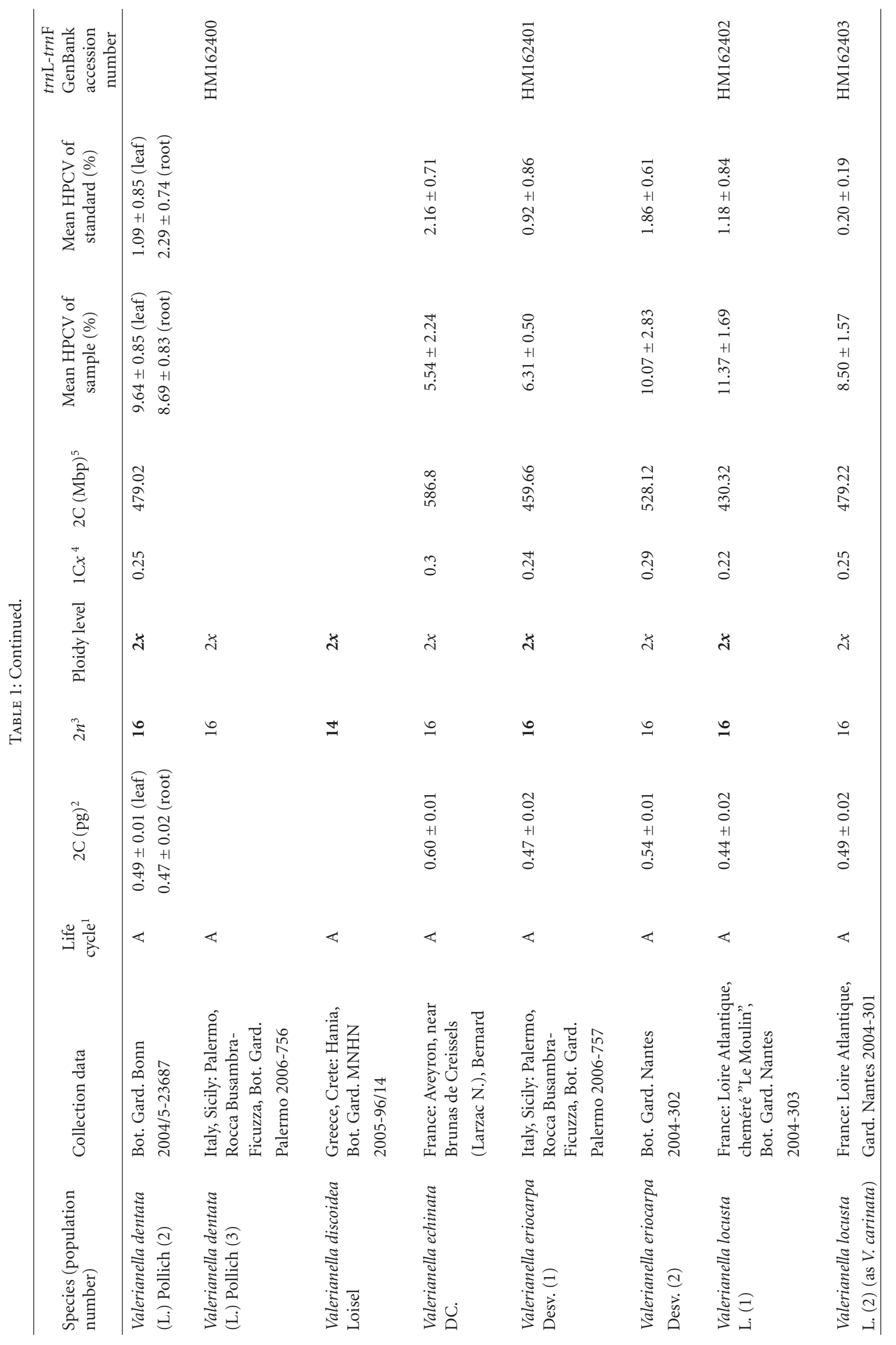




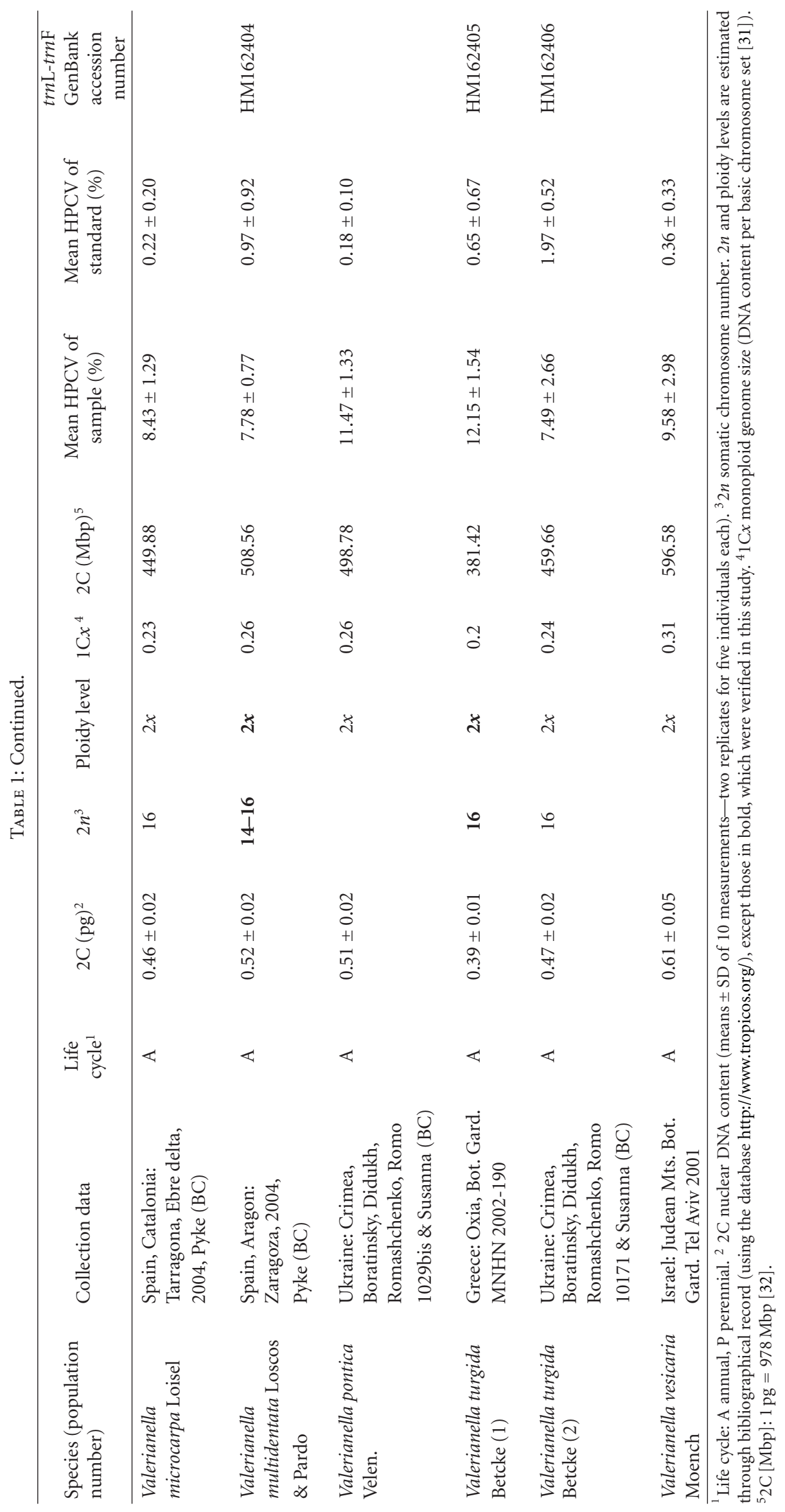


signal from 10-nm fluorescent beads (Immunocheck, Epics Division, Coulter Corporation). Time was used as a control for the stability of the instrument. Red fluorescence was projected onto a 1,024 monoparametric histogram. Gating single cells by their area versus peak fluorescence signal excluded aggregates. Acquisition was automatically stopped at 8,000 nuclei. Measurements were made at the Serveis Cientificotècnics (Universitat de Barcelona).

2.2.3. Effect of Valepotriates on Measurements. Valerianaceae contain, inter alia, valepotriates, a family of chemical compounds of great medicinal interest, thanks to which some representatives are considerably exploited by the pharmaceutical industry. Valepotriates are known DNA intercalators (they do have severe effects on DNA in e.g., PCR amplifications) and might thus possibly influence genome size measurements by altering the hydrodynamic diameter of the DNA. Furthermore, they could constitute endogenous staining inhibitors, which affect results by causing stoichiometric errors [35, and references therein]. Valepotriates are mainly stored in oil vesicles in the roots and rhizomes [36]. Therefore, we performed measurements on some roots and compared them with DNA C-values obtained for leaves of the same individuals to detect a potential effect of these chemical compounds on genome size assessments if any.

2.2.4. Statistical Analyses. ANOVA and LSD test were performed with the Statgraphics Plus 5.1 program (Statistical Graphics Corp., USA).

\subsection{Phylogenetic Analyses}

2.3.1. DNA Extraction, Amplification and Sequencing. Total genomic DNA was extracted from silica-dried, herbarium voucher or fresh leaves using the Nucleospin Plant extraction kit (Macherey-Nagel, GmbH \& Co., Duren, Germany). PCRs were carried out with PTC100 (MJ Research, Inc.) research thermal cyclers in $25 \mu \mathrm{l}$ volume. The whole plastid $\operatorname{trn} \mathrm{L}-\operatorname{trn} \mathrm{F}$ region [including the $\operatorname{trn} \mathrm{L}$ intron, the $3^{\prime} \operatorname{trn} \mathrm{L}$ (UAA) exon, and the intergenic spacer between $\operatorname{trn} \mathrm{L}$ (UAA) and $\operatorname{trn} \mathrm{F}$ (GAA)] was amplified and sequenced with the universal primers trnL-c, forward, and trnL-f, reverse, and, in some cases, trnL-d, reverse, and trnL-e, forward [37]. The PCR amplification conditions used were $94^{\circ} \mathrm{C}, 1 \mathrm{~min} 35 \mathrm{sec} ; 34 \mathrm{x}$ $\left(93^{\circ} \mathrm{C}, 1 \mathrm{~min} ; 58^{\circ} \mathrm{C}, 1 \mathrm{~min} ; 72^{\circ} \mathrm{C}, 1 \mathrm{~min}\right) ; 72^{\circ} \mathrm{C}, 10 \mathrm{~min}$, and storage at $4^{\circ} \mathrm{C}$. PCR products were purified with QIAquick PCR Purification Kit (Qiagen, Valencia, California, USA) or with DNA Clean \& Concentrator-5 D4003 (Zymo Research, Orange, California, USA). Direct sequencing of the amplified fragments was performed using the Big Dye Terminator Cycle Sequencing v3.1 (PE Biosystems, Foster City, California, USA). Nucleotide sequencing was carried out at the Serveis Cientificotècnics (Universitat de Barcelona) with an ABI PRISM 3700 DNA Analyzer (PE Biosystems, Foster City, California, USA).

2.3.2. Sequence Assembly, Alignment, and Analyses. Nucleotide sequences were assembled and edited using MacClade
4.08 [38]. Bayesian inference (BI) was carried out with MrBayes version 3.1.2 [39]. The most appropriate nucleotide substitution models were chosen with MrModeltest version 2.3 [40]. Four Markov chains were run simultaneously for $1 \times 10^{6}$ generations, and these were sampled every 100 generations. Data from the first 1,000 generations were discarded as the burn-in period, after confirming that likelihood values were stabilized prior to the 1,000th generation. The $50 \%$ majority rule consensus trees and posterior probability (PP) of nodes were calculated from the pooled samples. We proceeded to an additional analysis, adding to the matrix the gap data codified with the Barriel method, as previously used for Valerianaceae in [3]. Partitioned dataset analysis was carried out for this dataset including the codified gaps. A gamma-shaped rate variation was stated for the codified data following the manufacturer's protocol, applying the model selected with MrModeltest for the DNA data.

\section{Results}

3.1. Chromosome Counts. Chromosome numbers of the populations studied are indicated in Table 1, and metaphase plates are presented in Figure 1. According to our data, we provide the first count for Valerianella multidentata Loscos \& Pardo. Ploidy levels ranging from diploid to octoploid were detected although diploid and tetraploid were predominantly reported. Good metaphase plates are quite difficult to obtain for Valerianaceae. In fact, this is certainly the main reason why only few chromosome studies have been carried out in the family, and that especially few chromosome pictures have been published to present.

3.2. Genome Size Assessments. Data on nuclear DNA content are presented in Figure 2 and Table 1. The present data are the first reports on nuclear DNA content in all the genera studied excepting Centranthus and in all the species studied of this genus except for C. ruber (L.) DC., which was to date the only member of the family with a known genome size [30]. Genome size in Valerianaceae varies about 21.3fold, from $2 \mathrm{C}=0.39 \mathrm{pg}$ (Valerianella turgida Betcke, $2 x$ ) to $2 \mathrm{C}=8.32 \mathrm{pg}$ (Valeriana officinalis, $8 x$ ). Although the half peak coefficients of variation (HPCV) are rather high for some species (in all cases but one of the genus Valerianella), their mean value is $4.62 \%$ for the target plants and $2.04 \%$ for the standards. More in-deep research is suitable in Valerianella to try and obtain measurements with better HPCV.

The difference in genome size between leaves and roots measured in the same population has been addressed for Valeriana officinalis (7) (leaves: 2C of $7.67-8.97 \mathrm{pg}$ and roots: $2 \mathrm{C}$ of $8.04-8.14 \mathrm{pg}$, at $95 \%$ confidence interval) and Valerianella dentata (L.) Pollich (2) (leaves: 2C of 0.485$0.495 \mathrm{pg}$ and roots: $2 \mathrm{C}$ of $0.464-0.476 \mathrm{pg}$, at $95 \%$ confidence interval). A significant difference has been detected for Valerianella dentata (ANOVA, $P=0.0036$ ), which may indicate a possible effect of valepotriates on genome size assessments in this species, also suggested by the especially high HPCV values found in this annual genus (Table 1). 

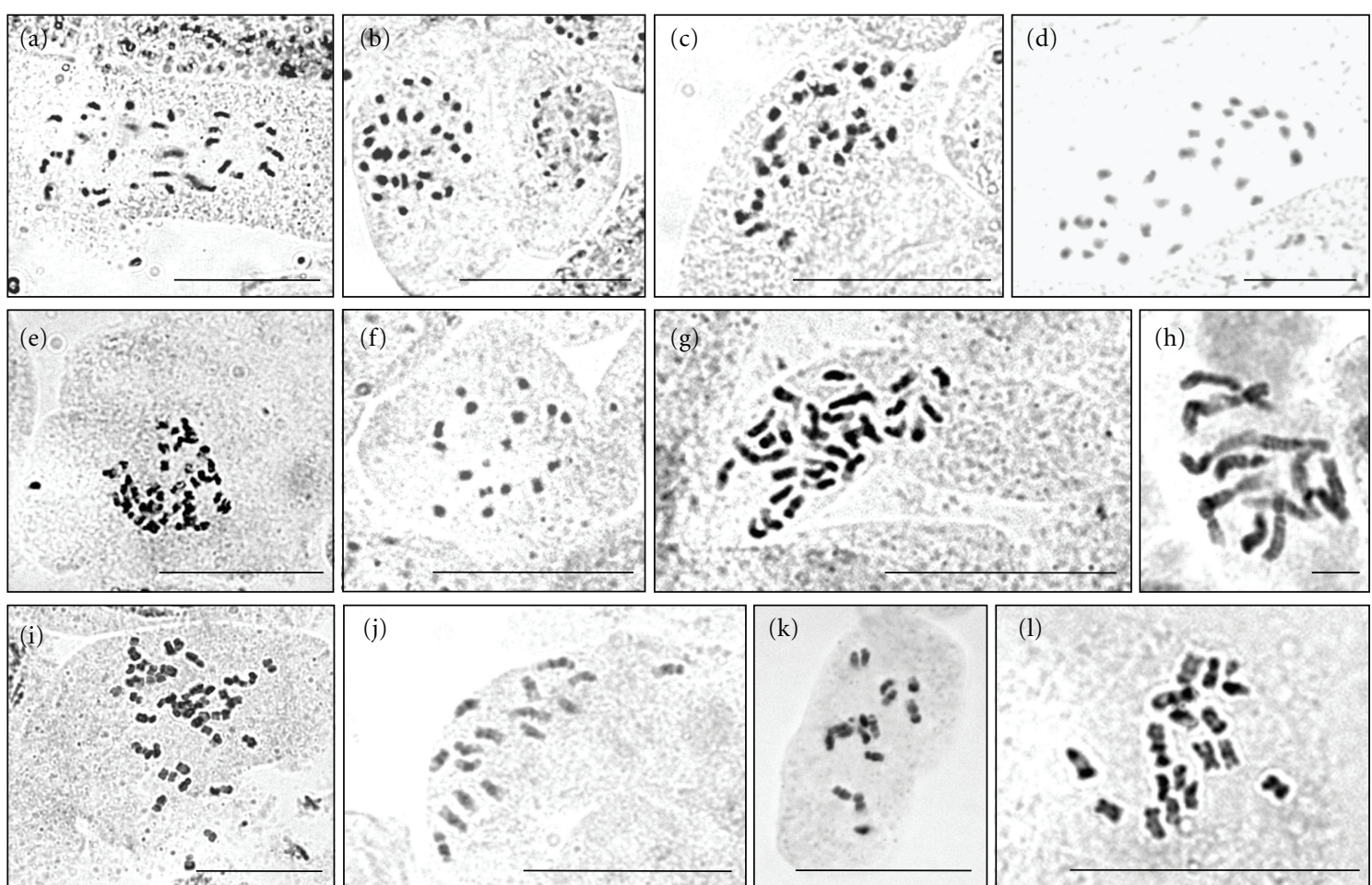

(j)
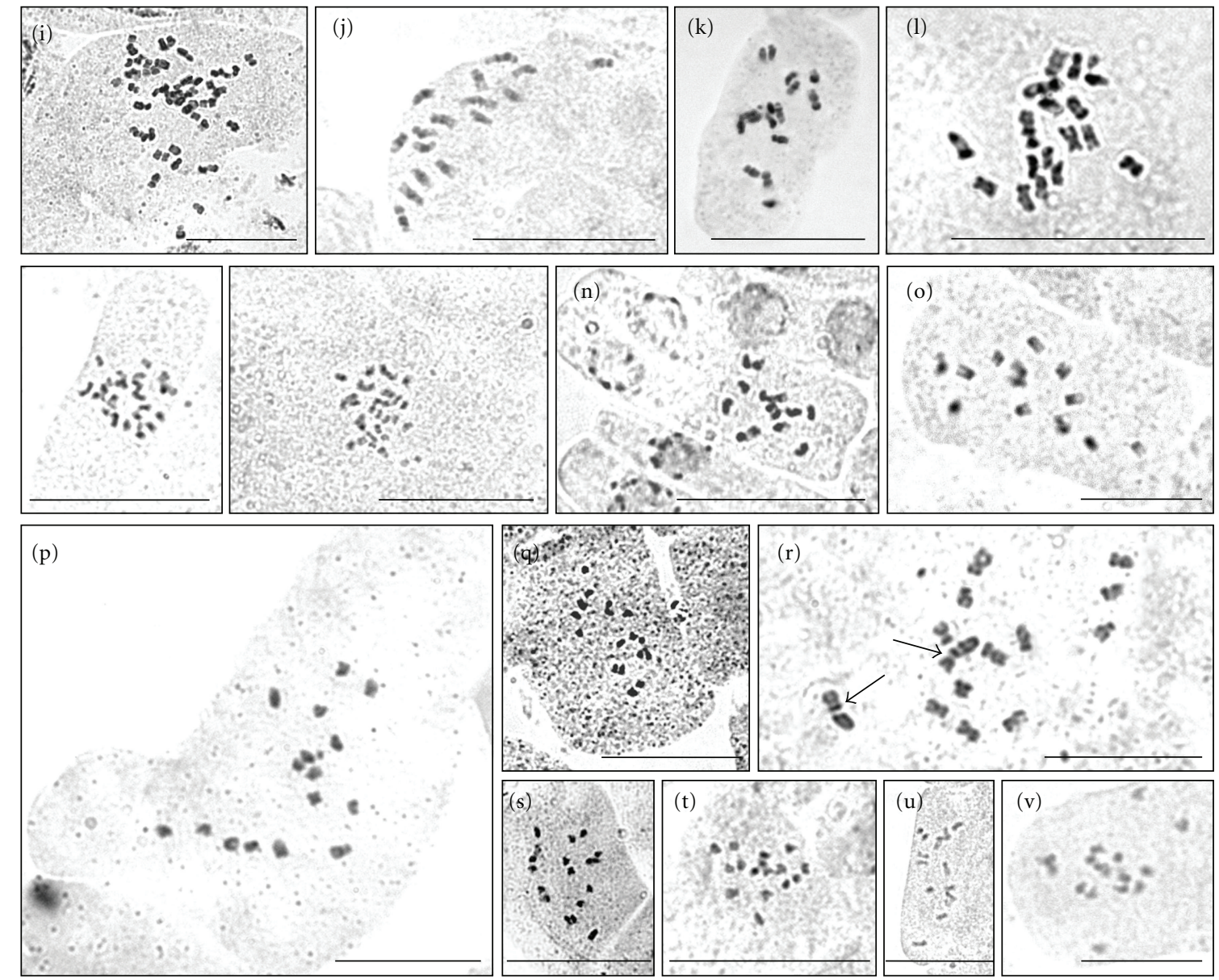

Figure 1: (a)-(v). Somatic metaphases. (a) Centranthus cf. calcitrapae (5), $2 n=32$. (b) C. lecoqii (2), $2 n=32$. (c) C. macrosiphon, $2 n=32$. (d) C. ruber (3), $2 n=32$. (e) Patrinia scabiosifolia, $2 n=$ ca. 44. (f) Valeriana apula $2 n=16$. (g) V. montana (5), $2 n=32$. (h) V. officinalis (1), $2 n=14$. (i) V. officinalis (6), $2 n=$ ca. 56. (j) V. pyrenaica, $2 n=16$. (k) V. saliunca, $2 n=16$. (1) V. tripteris (3), $2 n=18$. (ma-b) V. cf. tripteris (7), $2 n=32$. (n) Valerianella coronata (1), $2 n=14$. (o) V. coronata (2), $2 n=14$. (p) V. dentata (1), $2 n=16 .(\mathrm{q})$ $V$. dentata (2), $2 n=16$. (r) V. discoidea, $2 n=14$. Arrows indicate a chromosome pair much larger than the rest. (s) V. eriocarpa (1), $2 n=16$.

(t) V. locusta, $2 n=16$. (u) V. multidentata, $2 n=14-16$. (v) V. turgida (1), $2 n=16$. Scale bars $=10 \mu \mathrm{m}$. 


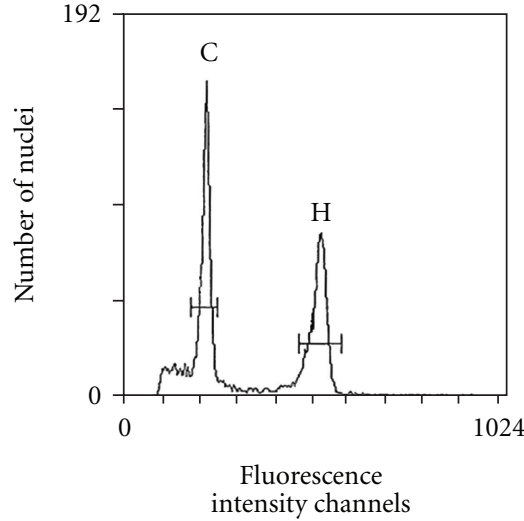

(a)

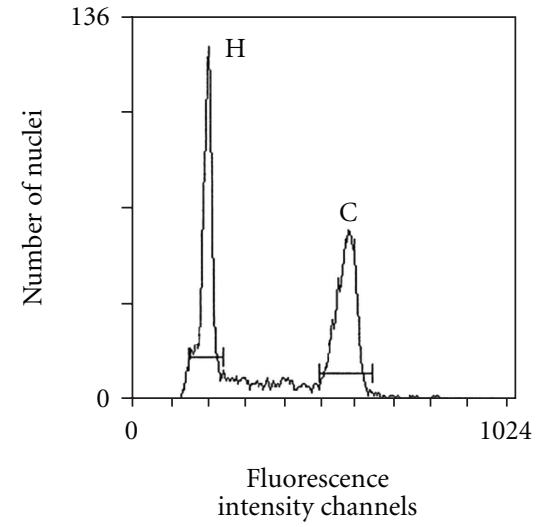

(b)

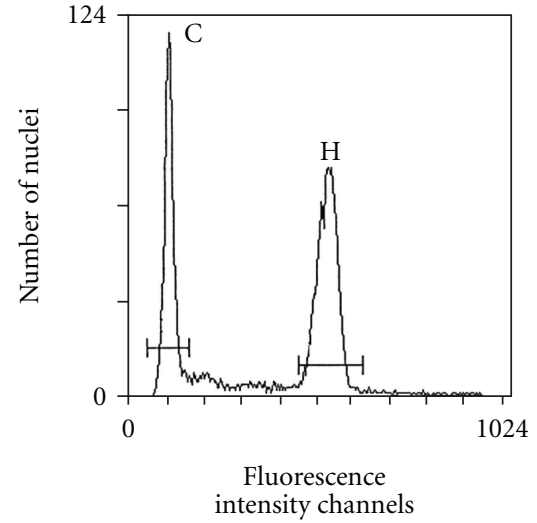

(c)

Figure 2: (a)-(c). Histograms of nuclear DNA content obtained for some representatives of Valerianaceae. (a) Centranthus nevadensis (2) $(2 \mathrm{C}=1.19 \pm 0.01)$. (b) Valeriana officinalis $(7)(2 \mathrm{C}=8.32 \pm 0.10)$. (c) Valerianella coronata (2) $(2 \mathrm{C}=0.53 \pm 0.01)$. Peak C: sample species nuclei. Peak H: standard species nuclei.

3.3. Molecular Phylogeny. Both AIC (Akaike Information Criterion) and hLRT (hierarchical Likelihood Ratio Tests) selected GTR+G (General Time Reversible model with gamma distribution) as the best-fit model. The results of the Bayesian analyses are presented in Figure 3. Phylogenetic trees obtained through the analyses of the two different datasets basically led to the same tree topology and supports. Nevertheless, three clades are only significantly supported when codified gap information is taken into account. These are (a) Valeriana clade I $(\mathrm{PP}=0.95$, Figure 3$)$, (b) Valeriana longiflora Willk. plus Centranthus clade $(\mathrm{PP}=$ 1.00, Figure 3), and (c) the grouping of Fedia cornucopiae (L.) Gaertn. AF446986 with Fedia graciliflora Fisch. \& C.A.Mey. $(\mathrm{PP}=0.96$, Figure 3$)$.

\section{Discussion}

We address here the analysis of genome size variation and its phylogenetic and taxonomical implications in the taxa considered.

4.1. The Basal Grades. They consist of the taxa showing the most ancestral characters within the Valerianaceae, namely, the genera Nardostachys and Patrinia, along with the clade grouping Valeriana celtica and Valeriana saxatilis L. (Valeriana clade III, Figure 3). Shifts in biogeography, flower morphology, and basic chromosome number occurred at this point of the evolutionary history of the family. From this moment on, the distribution area of the Valerianaceae, until that time restricted to Asia (Nardostachys and Patrinia), was enlarged to the other continents. At the same time the number of stamens decreased from four to three. These changes just preceded the change in basic chromosome numbers from $x=11$ to $x=8$, occurring at the arising of Valerianeae tribe (Figure 3).

The Valeriana clade III ( $\mathrm{P}=1.00$, Figure 3$)$ constituted by two species from the Alps, V. celtica and V. saxatilis, is branched between Patrinieae and Valerianeae, a position that was previously found for $V$. celtica $[4,5]$, and stated for the first time here for $V$. saxatilis. Although their genome sizes fall within the range of the remaining Valeriana, these two valerian species present $x=11$ as basic chromosome number $[41,42]$, which had only been detected in Patrinia. Furthermore, V. celtica has a yellow corolla, also like species of Patrinia. Nevertheless, species of clade III differ from Patrinia by a pappus-like Centranthus and Valeriana, and the number of stamens reduced to three as in Valeriana and Valerianella (whereas Nardostachys presents four and occasionally five stamens and Patrinia presents five or less stamens; $[43,44])$. Therefore, species of clade III are from morphological, cytogenetic, and phylogenetic points of view in between Patrinieae and Valerianeae. These results raise numerous questions. Should this clade III form a new genus? Could any other Valeriana species be susceptible to join this group? Then, should this group be classified within Valerianeae, or as a new tribe (their inclusion in the Patrinieae being impossible under the monophyly criterion)?

4.2. Fedia Plus Valerianella Clade. These species have the smallest genome sizes known in the family (Table 1) to present. Fedia and Valerianella are exclusively composed of annual herbaceous plants. All the species belonging to these two genera, excepted F. pallescens (Maire) Mathez, are common weeds in waste ground and cultivated land. Valerianella, which comprises around 50 species that are mainly diploid and with three stamens, is widely distributed in Eurasia, Africa and America. The genus Fedia includes only three tetraploid species and one hexaploid subspecies [45], with two stamens, and is restricted to the Mediterranean region. Molecular inferences suggest that Fedia species should have originated from Valerianella (Figure 3; [7]), in other words that autogamous strongly associate to anthropogenic environment (Valerianella) would have given rise to allogamous, polyploid (Fedia).

Genome size in those genera shows that Fedia (1Cx= 0.29 to $0.45 \mathrm{pg}$ ) has significantly higher DNA values than 


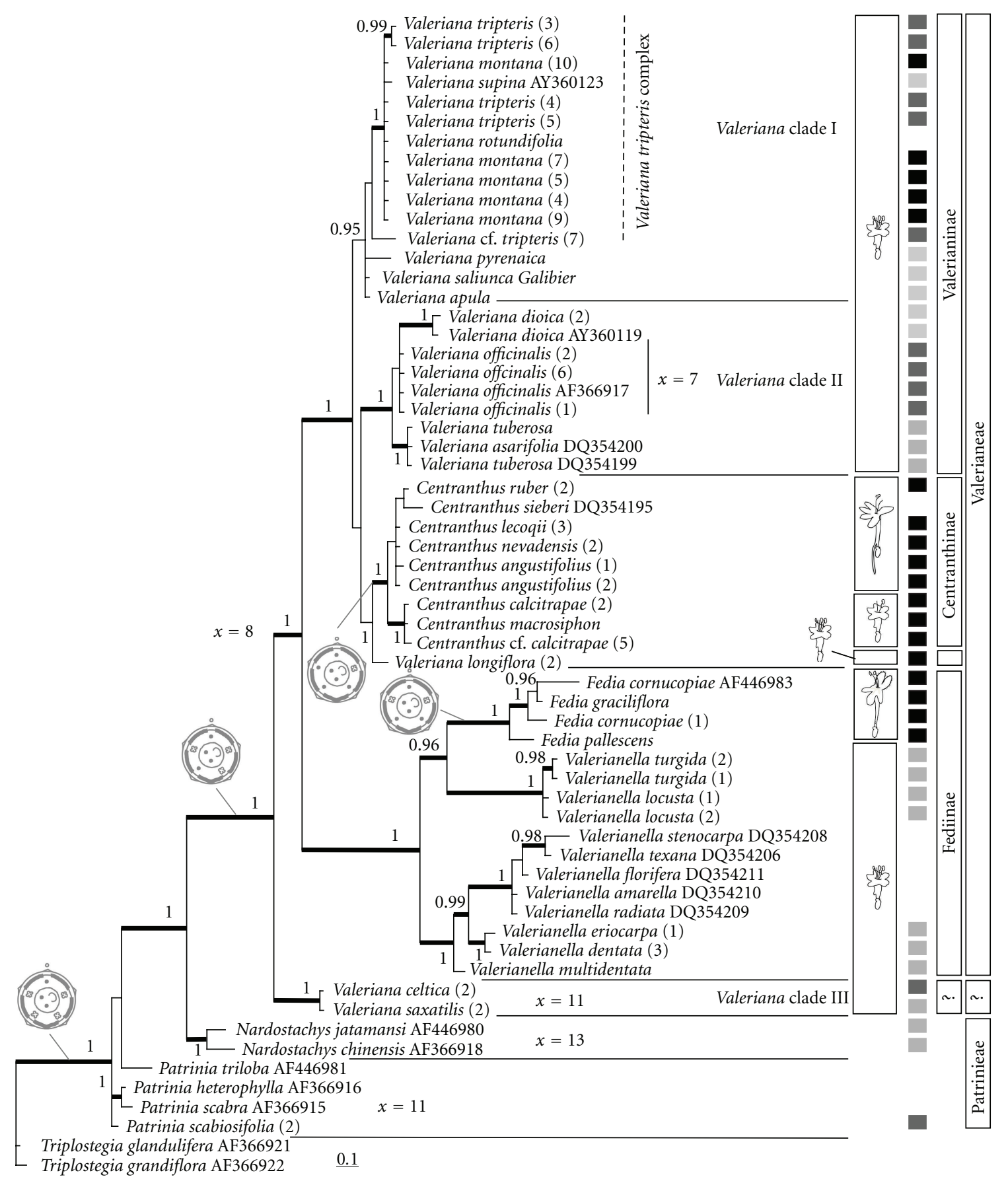

Species known only at diploid level

Species known at diploid and polyploid levels

Species known only at polyploid level

FIGURE 3: Molecular phylogeny based on the Bayesian analysis of the $\operatorname{trn} \mathrm{L}$-trnF region and the codified gap information, with posterior probability values $\geq 0.95$ indicated on the branches. Wider branches are those significantly supported in the Bayesian analysis of the trnL-trnF region without including the information from the gaps. Taxonomic information, relevant floral characters, basic chromosome number, and data on ploidy levels are indicated. GenBank accession numbers are provided for the previously published sequences. Numbers in brackets differentiate populations of a same species (see Table 1). 
Valerianella (from $1 \mathrm{C} x=0.20$ to $0.31 \mathrm{pg})(P=0.0000)$, which corroborates the conclusions of Albach \& Greilhuber [46] that allogamy is related to higher DNA values than autogamy. Furthermore, Fedia presents the "allogamy syndrome," morphological adaptations linked to the breeding system (e.g., zygomorphic corolla, development of a nectar gibbosity, tube elongation, and occurrence of polychroic corolla). The intensity of this syndrome varies between the species and the subspecies of Fedia [47]. The tendency within the genus is toward an increasing genome size and degree of allogamy syndrome, from Fedia pallescens $(1 \mathrm{C} x=0.29 \mathrm{pg})$ to $F$. graciliflora $(1 \mathrm{C} x=0.38 \mathrm{pg})$ and $F$. cornucopiae $(1 \mathrm{C} x=$ 0.43-0.45 pg).

The Valerianella group splits in two major clades (Figure 3), one including V. turgida, V. locusta (L.) Laterr., and the Fedia species. The genus Valerianella is revealed in this study as a relatively homogeneous group respecting genome size within Valerianaceae, with $2 \mathrm{C}$ values that range from $0.39 \mathrm{pg}$ ( $V$. turgida) to $0.61 \mathrm{pg}$ ( $V$. vesicaria Moench). Furthermore, some of Valerianella species, such as V. turgida, account for very small genomes, which fall into the range of the smallest genome size records in angiosperms [48], around the same scale than Arabidopsis thaliana (L.) Heynh. $(1 \mathrm{C}=0.16 \mathrm{pg} ;$ [49]), for long considered as the lowest angiosperms C-DNA value, nowadays reported in the genus Genlisea (G. margaretae 1C $=0.064$ pg; [50]).

The chromosome number of Valerianella multidentata, $2 n=2 x=14-16$, is reported here for the first time. This endemic restricted to a small area of Catalonia, Spain, is very close to $V$. discoidea Loisel (see [51]; $2 n=2 x=14-16$ ), which has been in turn related to V. coronata (L.) DC. ([52]; $2 n=2 x=14)$. All these species belong to section Coronatae. The chromosome number of $2 n=14$ is the smaller within the genus. Metaphase plates of $V$. discoidea (Figure $1(\mathrm{r})$ ) show a chromosome pair much larger than others that may result from a chromosome fusion sparking off the descending diploidy observed in the section.

4.3. Centranthus Plus Valeriana longiflora Clade. Centranthus is a circum-Mediterranean genus of nine species, characterized by flowers with one stamen, related to Valeriana longiflora $(\mathrm{PP}=1.00$, Figure $3 ;[5])$. All the species show the same chromosome number, $2 n=4 x=32$, both annuals (C. calcitrapae (L.) Dufr., C. macrosiphon Boiss.) and perennials (the other species), and both widespread (C. calcitrapae, C. ruber) and narrowly distributed species (the remaining). Centranthus is organized in three sections: Section Calcitrapae (C. calcitrapae and C. macrosiphon), sect. Centranthus (represented in our study by $C$. angustifolius (Mill.) DC., C. lecoqii Jord., C. longiflorus Stev. and C. ruber), and sect. Nervosa (not represented in our study). In this case, section Calcitrapae, annual ( $1 \mathrm{C} x=0.39-0.49 \mathrm{pg}$ ), has higher genome size than section Centranthus, perennial $(1 \mathrm{C} x=$ $0.29-0.36 \mathrm{pg}$ ). Annual plants have been usually reported to account for smaller genome sizes than perennials [53], as it is comprehensible that the transcriptional machinery would be more efficient in smaller genomes, in order to quickly complete the life-cycle. Otherwise, exceptions to this rule have been found in different plant groups $[22,54]$, and this seems to be the trend in the genus Centranthus.

The common occurrence of hybridization events in the overlapping areas of Centranthus species [55], and the fact that some species or infraspecific taxa show intermediate morphological characters, can indicate that several of these taxa could have a hybrid origin. As it has been reported in different plant groups, nuclear DNA content of hybrids corresponds to approximately the mean of both parental genome sizes, or is slightly smaller/larger than expected [26, 27, 56-64]. Within the section Calcitrapae, representatives of southern Spain and Morocco have a doubtful taxonomic assignation, somewhere between $C$. calcitrapae and $C$. macrosiphon ([55] for southern Spain; e.g., J Mathez, Université Montpellier II, France, "unpubl. res." for Morocco). One population of Morocco was assessed, C. cf. calcitrapae (5), and the $1 \mathrm{C} x$ value obtained of $0.45 \mathrm{pg}$ turns out to be the average between the means of typical $C$. calcitrapae $(1 \mathrm{C} x=0.40 \mathrm{pg})$ and $C$. macrosiphon $(1 \mathrm{C} x=0.49 \mathrm{pg})$, this being consistent with the hypothesis of a hybrid origin for this Moroccan population. Also, C. lecoqii is morphologically intermediate between C. angustifolius and C. ruber [55]. The $1 C x$ amount of $C$. lecoqii $(0.31 \mathrm{pg})$, the mean of those of C. angustifolius ( $0.34 \mathrm{pg}$ ) and C. ruber $(0.29 \mathrm{pg})$, is compatible with the hypothesis of a hybrid origin for the former taxon.

4.4. Valeriana montana Clade. This group of alpine plants is constituted by species with hermaphrodite flowers and of restricted area ( $V$. saliunca All. and $V$. supina Ard. from the Alps, V. pyrenaica L. and V. apula Pourr. from the Pyrenees), two gynodioecious species widely distributed, $V$. tripteris L. and V. montana L. (from the mountains of Southern Europe). Valeriana rotundifolia Vill. is a gynodioecious taxon of obscure status, present in the Alps and Corsica, and morphologically close to $V$. tripteris and V. montana [65]. The molecular phylogeny shows a Valeriana tripteris complex constituted by the populations of $V$. montana, $V$. rotundifolia, $V$. supina and $V$. tripteris, who are forming a robust clade $(\mathrm{PP}=1.00$, Figure 3$)$, with the exception of $V$. cf. tripteris (7) that is sister to the remaining ones. This result raises the question of the monophyly of $V$. tripteris, but also shows a possible interesting biogeographical pattern as the population $V$. cf. tripteris (7) is the only sequenced that grows at the east of the Alps. Furthermore, this population is not only divergent in terms of DNA sequence, but also for its cytogenetic characters. Although V. cf. tripteris (7) is a tetraploid (Figure $1 \mathrm{ma}-\mathrm{b}$ ), its genome size $2 \mathrm{C}=1.23 \mathrm{pg}$ ranks low if compared with tetraploid $V$. montana (2C $=2.50-2.60 \mathrm{pg})$, and even with diploid $V$. tripteris $(2 \mathrm{C}=$ $1.46-1.51 \mathrm{pg})$.

Intermediate forms between $V$. tripteris and $V$. montana, such as V. cf. montana (11-12), V. cf. tripteris (7) or V. rotundifolia, occur throughout the range of distribution, which makes their taxonomic delimitation difficult. This is the reason why these taxa have been sometimes considered to represent a single species with various subspecific entities, and also as two closely related species with their intermediate 
forms as subspecies (see [65], and references therein). Cryptic hybrid and/or polyploid taxa may largely account for the taxonomic heterogeneity of $V$. tripteris complex and the genome size variation observed in the group, especially at intraspecific level. However, Briquet \& Cavillier [65] pointed out that intermediate forms are found in isolated populations, without $V$. montana, which makes their hybrid origin improbable and their polyploid origin from $V$. tripteris maybe more likely. Should this polyploid hypothesis be sustained, the question remains as to why tetraploid $V$. tripteris are morphologically similar to $V$. montana. One explanation could be that the speciation of $V$. montana could have also been induced by a polyploidization event of $V$. tripteris, which would have arisen previously in evolutionary time. This would explain both the more notable morphological and ecological differentiation between the two species, and in some cases the more important decrease in monoploid genome size with respect to that of the intermediate forms [23].

4.5. Valeriana officinalis Clade (Valeriana Clade II, Figure 3). Valeriana officinalis and relatives constitute a difficult complex of numerous taxa of specific and infraspecific ranges, with doubtful morphological delimitation. Valeriana officinalis presents an unusual basic chromosome number for the genus of $x=7$. This basic number is also found in V. wallrothii Kreyer, a species closely related to Valeriana officinalis in the molecular phylogeny [6], but not in other representatives of the group as, for example, $V$. dioica or $V$. tuberosa. The populations of $V$. officinalis measured exhibit different DNA amounts, suggesting four different DNA ploidy levels of $2 x, 4 x, 6 x$, and $8 x$ (Table 1). Even so, it would be necessary to determine whether those differences really correspond to different ploidy levels, or if they are partially due to a high intraspecific variability within $V$. officinalis. This doubt concerns particularly the ploidy levels that are uncommon in the $V$. officinalis complex, like the hexaploid level (corresponding to 42 chromosomes), known only from V. coreana Briq. [66] and V. transjenisensis Kreyer [67]. The results compiled in the present study allow us to conclude that the complexity within $V$. officinalis, in which polyploidization events are largely implicated, is much more than previously considered.

\section{Concluding Remarks}

At the family level, changes in basic chromosome number and genome size coincide with or precede major shifts in the evolutionary history of Valerianaceae. One interesting example is the arising of strong zygomorphic flower in Centranthus and Fedia, which is in both cases consecutive to a polyploidization event. Therefore, cytogenetic studies are essential for understanding the family, and, in this sense, we will follow our effort for providing new data of this type, especially in those genera poorly studied or unknown at different levels (i.e., genome size) such as Plectritis.

\section{Acknowledgments}

The authors acknowledge S Siljak-Yakovlev for useful comments for improving the chromosome count protocol, and J Suda and three anonymous reviewers for valuable suggestions on the draft. They thank M Bou Dagher-Kharrat, R Douzet, M Casanovas, C Hidalgo, Odile Hidalgo, JM Martin, N Martin, S Pyke, ML Revel-Hidalgo, K Romashchenko, À Romo and I Soriano for their assistance with collections, N Xena de Enrech and M-B Raymúndez for helpful comments, SC Brown and O Catrice for supplying Petunia hybrida and Pisum sativum used as internal standards, R Álvarez, J Comas, R López and R Martínez for technical support in flow cytometry, M Veny for keeping the collections of living plants, and S Pyke for the amelioration of the English language. The collaboration of the botanical gardens and herbaria listed in Table 1 is also acknowledged. This work was subsidized by the Dirección General de Enseñanza Superior, Spain (Project PB 97/1134), the Ministerio de Ciencia y Tecnología, Spain (projects CGL2007-64839-C02-01 and C02-02/BOS) and the Generalitat de Catalunya ("Ajuts a grups de recerca consolidats" 2005/SGR/00344). O Hidalgo received an MICINN postdoctoral grant from the Ministerio de Ciencia e Innovación, Spain and S Garcia a JAE Doc contract from the CSIC, Spain.

\section{References}

[1] APG III, "An update of the Angiosperm Phylogeny Group classification for the orders and families of flowering plants: APG III," Botanical Journal of the Linnean Society, vol. 161, no. 2, pp. 105-121, 2009.

[2] C. D. Bell, E. J. Edwards, S.-T. Kim, and M. J. Donoghue, "Dipsacales phylogeny based on chloroplast DNA sequences," Harvard Papers in Botany, vol. 6, pp. 481-499, 2001.

[3] M. B. Raymúndez, J. Mathez, N. Xena de Enrech, and J.-Y. Dubuisson, "Coding of insertion-deletion events of the chloroplastic intergene atp $\beta-r b c \mathrm{~L}$ for the phylogeny of the Valerianeae tribe (Valerianaceae)," Comptes Rendus de l'Académie des Sciences de Paris, Biologie, vol. 325, no. 2, pp. 131-139, 2002.

[4] C. D. Bell, "Preliminary phylogeny of Valerianaceae (Dipsacales) inferred from nuclear and chloroplast DNA sequence data," Molecular Phylogenetics and Evolution, vol. 31, no. 1, pp. 340-350, 2004.

[5] O. Hidalgo, T. Garnatje, A. Susanna, and J. Mathez, "Phylogeny of Valerianaceae based on matK and ITS markers, with reference to matK individual polymorphism," Annals of Botany, vol. 93, no. 3, pp. 283-293, 2004.

[6] C. D. Bell and M. J. Donoghue, "Phylogeny and biogeography of Valerianaceae (Dipsacales) with special reference to the South American valerians," Organisms Diversity and Evolution, vol. 5, no. 2, pp. 147-159, 2005.

[7] C. D. Bell, "Phylogenetic placement and biogeography of the North American species of Valerianella (Valerianaceae: Dipsacales) based on chloroplast and nuclear DNA," Molecular Phylogenetics and Evolution, vol. 44, no. 3, pp. 929-941, 2007.

[8] A. P. de Candolle, Prodromus Systematis Naturalis Regni Vegetabilis IV, Treuttel and Würtz, London, UK, 1830.

[9] F. Höck, "Verwandtschaftsbeziehungen der Valerianaceen und Dipsacaceen," Botanischer Jahrbücher für Systematik, 
Pflanzengeschichte und Pflanzengeographie, vol. 3, pp. 1-73, 1902.

[10] P. Graebner, "Die Gattungen der natürlichen Familie der Valerianaceae," Botanischer Jahrbücher für Systematik, Pflanzengeschichte und Pflanzengeographie, vol. 37, pp. 464-480, 1906.

[11] F. Weberling, "Familie Valerianaceae," in Illustrierte Flora von Mitteleuropa, G. Wagenitz, Ed., pp. 97-176, Carl Hanser, München, Germany, 1970.

[12] B. Eriksen, "Notes on generic and infrageneric delimitation in the Valerianaceae," Nordic Journal of Botany, vol. 9, pp. 179187, 1989.

[13] F. Weberling, "Die Infloreszenzen der Valerianaceen und ihre systematische Bedeutung," in Abhandlungen der Mathematisch-Naturwissenschaftlichen Klasse, vol. 5, pp. 150-281, Akademie der Wissenschaften, Berlin, Germany, 1961.

[14] O. Hidalgo, Inflorescences et Phylogénie des Valerianaceae, Mémoire de DEA Systématique Animale et Végétale, Université Paris VI, Paris, France; Université Lyon I, Lyon, France, 1999.

[15] M. J. Donoghue, C. D. Bell, and R. C. Winkworth, "The evolution of reproductive characters in Dipsacales," International Journal of Plant Sciences, vol. 164, no. 5, pp. S453-S464, 2003.

[16] D. G. Howarth and M. J. Donoghue, "Duplications in CYC-like genes from Dipsacales correlate with floral form," International Journal of Plant Sciences, vol. 166, no. 3, pp. 357370, 2005.

[17] D. G. Howarth and M. J. Donoghue, "Duplications and expression of DIVARICATA-like genes in Dipsacales," Molecular Biology and Evolution, vol. 26, no. 6, pp. 1245-1258, 2009.

[18] D. G. Howarth and M. J. Donoghue, "Phylogenetic analysis of the "ECE" (CYC/TB1) clade reveals duplications predating the core eudicots," Proceedings of the National Academy of Sciences of the United States of America, vol. 103, no. 24, pp. 9101-9106, 2006.

[19] D. E. Soltis, H. Ma, M. W. Frohlich et al., "The floral genome: an evolutionary history of gene duplication and shifting patterns of gene expression," Trends in Plant Science, vol. 12, no. 8, pp. 358-367, 2007.

[20] D. E. Soltis, V. A. Albert, J. Leebens-Mack et al., "Polyploidy and angiosperm diversification," American Journal of Botany, vol. 96, no. 1, pp. 336-348, 2009.

[21] K. Engel, Beiträge zur Systematik der Valerianaceae unter besonderes, Ph.D. thesis, Berucksichtigung Cytosystematischer Ergebnisse, Giessen, Germany, 1976.

[22] T. Garnatje, J. Vallès, S. Garcia et al., "Genome size in Echinops L. and related genera (Asteraceae, Cardueae): karyological, ecological and phylogenetic implications," Biology of the Cell, vol. 96, no. 2, pp. 117-124, 2004.

[23] H. Weiss-Schneeweiss, J. Greilhuber, and G. M. Schneeweiss, "Genome size evolution in holoparasitic Orobanche (Orobanchaceae) and related genera," American Journal of Botany, vol. 93, no. 1, pp. 148-156, 2006.

[24] I. J. Leitch, J. M. Beaulieu, K. Cheung, L. Hanson, M. A. Lysak, and M. F. Fay, "Punctuated genome size evolution in Liliaceae," Journal of Evolutionary Biology, vol. 20, no. 6, pp. 2296-2308, 2007.

[25] I. J. Leitch, I. Kahandawala, J. Suda et al., "Genome size diversity in orchids: consequences and evolution," Annals of Botany, vol. 104, no. 3, pp. 469-481, 2009.

[26] T. Garnatje, S. Garcia, R. Vilatersana, and J. Vallès, "Genome size variation in the genus Carthamus (Asteraceae, Cardueae): systematic implications and additive changes during allopolyploidization," Annals of Botany, vol. 97, no. 3, pp. 461-467, 2006.

[27] I. J. Leitch, L. Hanson, K. Y. Lim et al., "The ups and downs of genome size evolution in polyploid species of Nicotiana (Solanaceae)," Annals of Botany, vol. 101, no. 6, pp. 805-814, 2008.

[28] J. Pellicer, M. Á. Canela, S. Garcia, et al., "Genome size dynamics in Artemisia L. (Asteraceae): following the track of polyploidy," Plant Biology. In press.

[29] B. G. Murray, "When does intraspecific C-value variation become taxonomically significant?" Annals of Botany, vol. 95, no. 1, pp. 119-125, 2005.

[30] L. Hanson, K. A. McMahon, M. A. T. Johnson, and M. D. Bennett, "First nuclear DNA C-values for 25 angiosperm families," Annals of Botany, vol. 88, pp. 851-858, 2001.

[31] J. Greilhuber, J. Doležel, M. A. Lysák, and M. D. Bennett, "The origin, evolution and proposed stabilization of the terms 'genome size' and 'C-value' to describe nuclear DNA contents,' Annals of Botany, vol. 95, no. 1, pp. 255-260, 2005.

[32] J. Doležel, J. Bartoš, H. Voglmayr, and J. Greilhuber, "Nuclear DNA content and genome size of trout and human (multiple letters)," Cytometry Part A, vol. 51, no. 2, pp. 127-129, 2003.

[33] J. Doležel, P. Binarová, and S. Lucretti, "Analysis of nuclear DNA content in plant cells by flow cytometry," Biologia Plantarum, vol. 31, no. 2, pp. 113-120, 1989.

[34] D. Marie and S. C. Brown, "A cytometric exercise in plant DNA histograms, with $2 \mathrm{C}$ values for 70 species," Biology of the Cell, vol. 78, no. 1-2, pp. 41-51, 1993.

[35] J. Loureiro, E. Rodriguez, J. Doležel, and C. Santos, "Flow cytometric and microscopic analysis of the effect of tannic acid on plant nuclei and estimation of DNA content," Annals of Botany, vol. 98, no. 3, pp. 515-527, 2006.

[36] A. Cronquist, The Evolution and Classification of Flowering Plants, The New York Botanical Garden, New York, NY, USA, 1988.

[37] P. Taberlet, L. Gielly, G. Pautou, and J. Bouvet, "Universal primers for amplification of three non-coding regions of chloroplast DNA," Plant Molecular Biology, vol. 17, no. 5, pp. 1105-1109, 1991.

[38] D. R. Maddison and W. P. Maddison, MacClade 4: Analysis of Phylogeny and Character Evolution. Version 4.08, Sinauer Associates, Sunderland, UK, 2005.

[39] F. Ronquist and J. P. Huelsenbeck, "MrBayes 3: Bayesian phylogenetic inference under mixed models," Bioinformatics, vol. 19, no. 12, pp. 1572-1574, 2003.

[40] J. A. A. Nylander, MrModeltest v2. Program Distributed by the Author, Evolutionary Biology Centre, Uppsala University, 2004.

[41] C. Favarger, "Sur quelques Valeriana endémiques des Alpes ou des Dinarides," Candollea, vol. 33, pp. 11-21, 1978.

[42] A. M. Benko-Iseppon, Karyologische Untersuchung der Caprifoliaceae s.l. und möglicher verwandter familien, Ph.D. thesis, Universität Wien, Wien, Austria, 1992.

[43] F. Weberling, "On the systematics of Nardostachys (Valerianaceae)," Taxon, vol. 24, pp. 443-452, 1975.

[44] N. Pyck, A. Van Lysebetten, J. Stessens, and E. Smets, "The phylogeny of Patrinieae sensu Graebner (Valerianaceae) revisited: additional evidence from ndhF sequence data," Plant Systematics and Evolution, vol. 233, no. 1-2, pp. 29-46, 2002.

[45] N. Xena de Enrech, M. À. Cardona, and J. Mathez, "Estudio citotaxonómico del género Fedia Gaertn. (Valerianaceae)," Anales del Jardín Botánico de Madrid, vol. 48, pp. 157-169, 1991. 
[46] D. C. Albach and J. Greilhuber, "Genome size variation and evolution in Veronica," Annals of Botany, vol. 94, no. 6, pp. 897-911, 2004.

[47] N. Xena de Enrech, Recherches biosystématiques sur le genre Fedia (Valerianaceae), Ph.D. thesis, Université des Sciences et Techniques du Languedoc, Montpellier, France, 1987.

[48] M. D. Bennett and I. J. Leitch, "Angiosperm DNA C-values database," release 6.0, October 2005, http://data.kew.org/cvalues.

[49] M. D. Bennett and I. J. Leitch, "Genome size evolution in plants," in The Evolution of the Genome, T. R. Gregory, Ed., pp. 89-162, Elsevier Academic Press, New York, NY, USA, 2005.

[50] J. Greilhuber, T. Borsch, K. Müller, A. Worberg, S. Porembski, and W. Barthlott, "Smallest angiosperm genomes found in Lentibulariaceae, with chromosomes of bacterial size," Plant Biology, vol. 8, no. 6, pp. 770-777, 2006.

[51] D. Ernet and I. B. K. Richarsdon, "Valerianella," in Flora Europaea Vol. 4. CLXVI. Valerianaceae, S. M. Walters, Ed., vol. 4, pp. 48-52, 1976.

[52] A. Martin and J. Mathez, "Polymorphisme et taxinomie chez les Valerianaceae: quelques indications sur les Valérianelles proches de Valerianella coronata," Naturalia Monspeliensia, vol. 55, pp. 61-75, 1990.

[53] A. E. Vinogradov, "Mirrored genome size distributions in monocot and dicot plants," Acta Biotheoretica, vol. 49, no. 1, pp. 43-51, 2001.

[54] S. Garcia, M. Sanz, T. Garnatje, A. Kreitschitz, E. D. McArthur, and J. Vallès, "Variation of DNA amount in 47 populations of the Subtribe Artemisiinae and related taxa (Asteraceae, Anthemideae): karyological, ecological, and systematic implications," Genome, vol. 47, no. 6, pp. 1004-1014, 2004.

[55] I. B. K. Richardson, "A revision of the genus Centranthus DC. (Valerianaceae)," Botanical Journal of the Linnean Society, vol. 71, no. 3, pp. 211-234, 1975.

[56] D. U. Gerstel and J. A. Burns, "Flower variegation in hybrids between Nicotiana tabacum and N. otophora," Genetics, vol. 53, pp. 331-338, 1966.

[57] J. H. Buitendijk, E. J. Boon, and M. S. Ramanna, "Nuclear DNA content in twelve species of Alstroemeria L. and some of their hybrids," Annals of Botany, vol. 79, no. 4, pp. 343-353, 1997.

[58] L. Comai, "Genetic and epigenetic interactions in allopolyploid plants," Plant Molecular Biology, vol. 43, no. 2-3, pp. 387399, 2000.

[59] J. L. Bennetzen, "Mechanisms and rates of genome expansion and contraction in flowering plants," Genetica, vol. 115, no. 1, pp. 29-36, 2002.

[60] B. Liu and J. F. Wendel, "Non-Mendelian phenomena in allopolyploid genome evolution," Current Genomics, vol. 3, no. 6, pp. 489-505, 2002.

[61] H. Ozkan, M. Tuna, and K. Arumuganathan, "Nonadditive changes in genome size during allopolyploidization in the wheat (Aegilops-Triticum) group," Journal of Heredity, vol. 94, no. 3, pp. 260-264, 2003.

[62] M. Šiško, A. Ivančič, and B. Bohanec, "Genome size analysis in the genus Cucurbita and its use for determination of interspecific hybrids obtained using the embryorescue technique," Plant Science, vol. 165, no. 3, pp. 663-669, 2003.

[63] P. Bureš, Y.-F. Wang, L. Horová, and J. Suda, "Genome size variation in Central European species of Cirsium (Compositae) and their natural hybrids," Annals of Botany, vol. 94, no. 3, pp. 353-363, 2004.

[64] S. Garcia, M. Á. Canela, T. Garnatje et al., "Evolutionary and ecological implications of genome size in the North American endemic sagebrushes and allies (Artemisia, Asteraceae)," Biological Journal of the Linnean Society, vol. 94, no. 3, pp. 631649, 2008.

[65] J. Briquet and F. Cavillier, "Valerianaceae," in Flore des Alpes Maritimes, E. Burnat, Ed., pp. 186-215, Georg \& Cie, Lyon, France, 1915.

[66] N. S. Probatova and A. P. Sokolovskaya, "Kariologicheskoe issledovanie sosudistykh rastenij ostrovov Dal'nevostočnogo gosudarstevennogo morskogo zapovednika," Sb. Cvetkaye Rastenija Ostrovov Dalnevostočnogo Morskogo Zapovednika, pp. 92-114, 1981.

[67] N. S. Probatova and A. P. Sokolovskaya, "Chromosome numbers in vascular plants from Primorye Territory, the Amur River basin, North Koryakia, Kamchatka and Sakhalin," Botaničeskij Žurnal, vol. 73, pp. 290-293, 1988. 

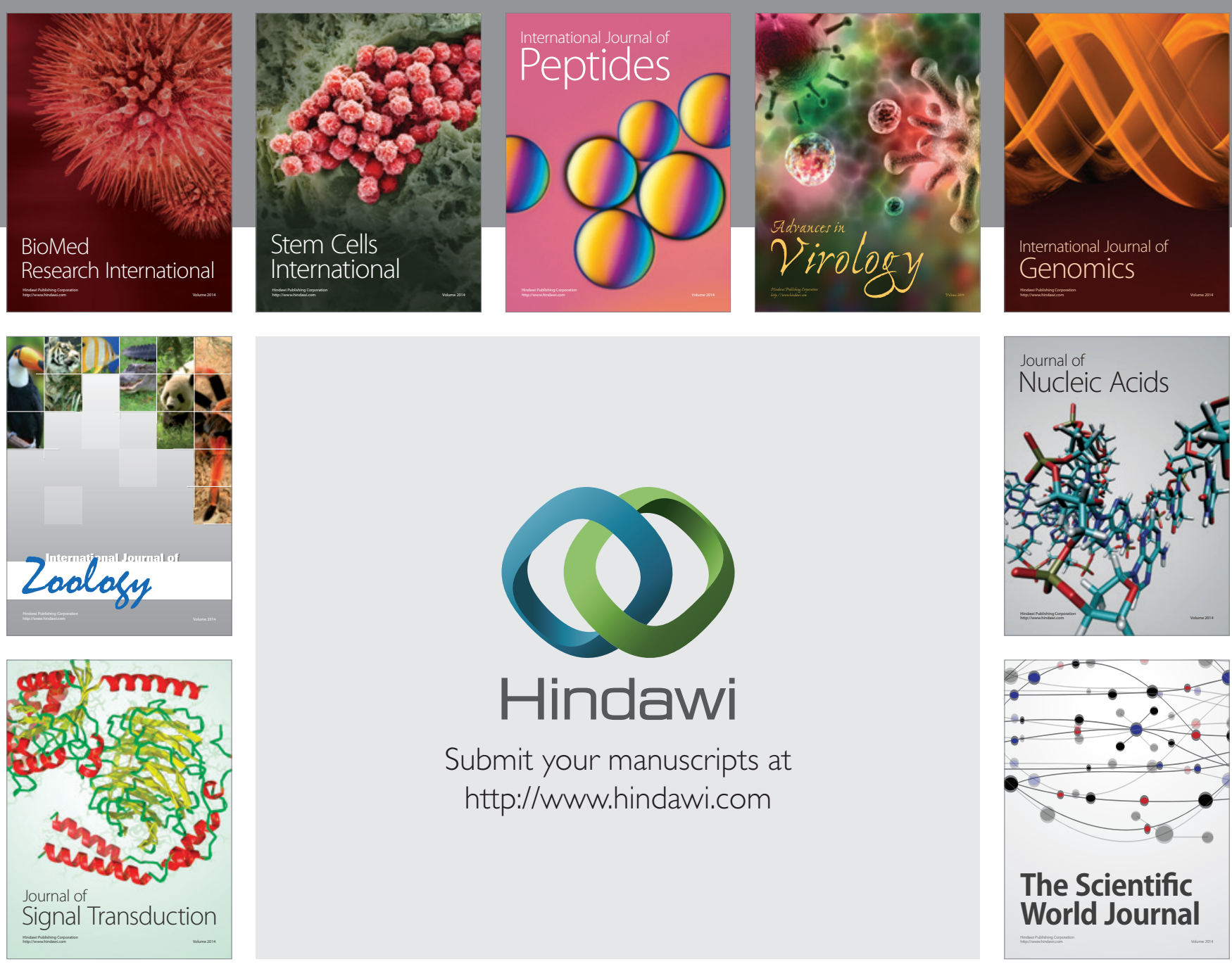

Submit your manuscripts at

http://www.hindawi.com
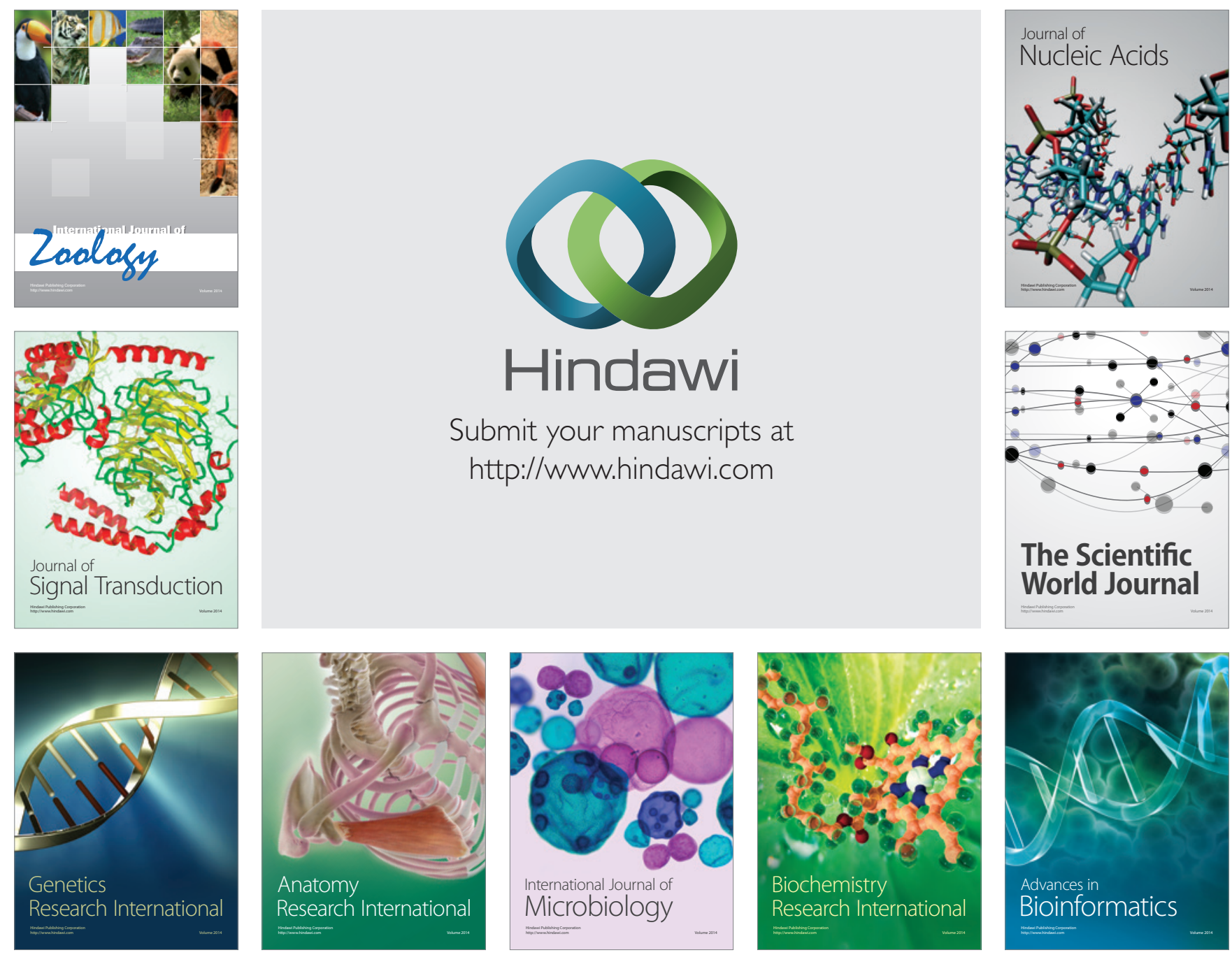

The Scientific World Journal
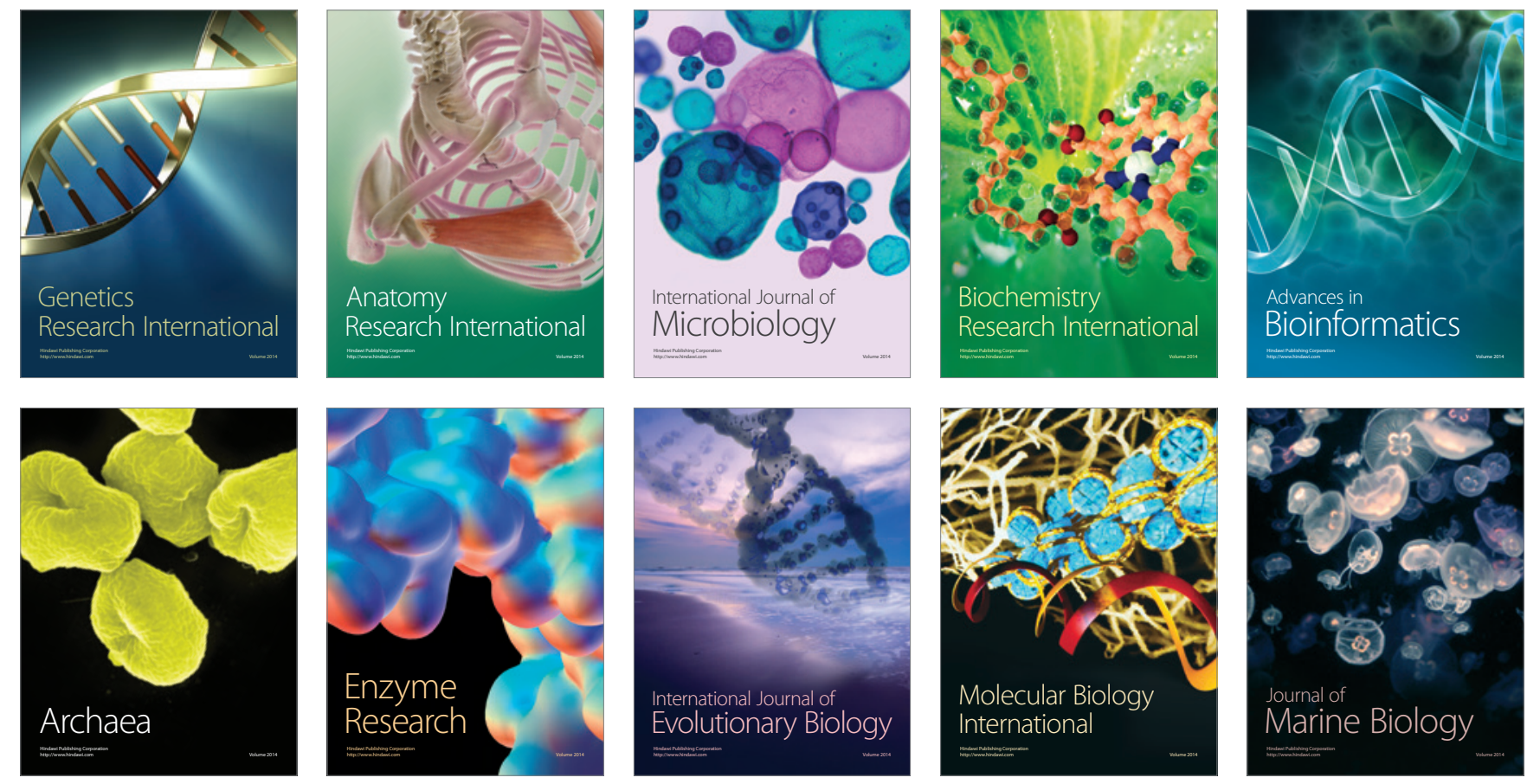